\title{
The impact of trade agreements on world export prices
}

\section{Lisandra Flach ${ }^{1}$ (D) | Fabian Gräf ${ }^{2}$}

\author{
${ }^{1}$ Ludwig-Maximilians-Universität \\ München, Munich, Germany \\ ${ }^{2}$ E.CA Economics, Berlin, Germany \\ Correspondence \\ Lisandra Flach, Department of Economics, \\ Ludwig-Maximilians-Universität München, \\ Ludwigstr. 28, Munich, Germany. \\ Email: lisandra.flach@econ.lmu.de

\section{Present address} \\ Lisandra Flach, Centre for Economic \\ Policy Research (CEPR), London, United \\ Kingdon and Center for Economic Studies \\ (CESifo), Munich, Germany
}

\section{Funding information}

German Science Foundation, Grant/Award Number: CRC TRR 190

\begin{abstract}
This paper uncovers new stylized facts on the relation between economic integration and world trade prices. Using free on board export price data for the universe of manufacturing products, we show that a country's membership in the WTO (World Trade Organization) or in a PTA (Preferential Trade Agreement) is associated with an increase in export prices of differentiated goods. For the WTO, this effect is captured by the countries that were subject to rigorous WTO accession procedures. We also exploit the importance of the depth of a PTA and of its different provisions. Whereas the effect of the depth per se is not significant, individual provisions evoke distinct effects on prices. In particular, we find that PTAs with provisions on investments are associated with higher export prices. The results are consistent with theoretical models that relate competition to the innovation behavior of firms.
\end{abstract}

J E L C L A S S I F I C A T I O N

F13; F14

\section{1 | INTRODUCTION}

A large empirical literature has investigated the trade promoting effects of membership in the WTO and in PTAs. ${ }^{1}$ However, little is known about the effect of trade agreements on world trade prices. ${ }^{2}$ Membership in trade agreements lowers trade barriers on imported goods, which decreases export prices through a cost-reducing effect. In contrast, lower trade barriers might increase access to more variety and better quality products (see Amiti \& Khandelwal, 2013; Fan, Li, \& Yeaple, 2015), affect This is an open access article under the terms of the Creative Commons Attribution License, which permits use, distribution and reproduction in any medium, provided the original work is properly cited.

(C) 2019 The Authors. Review of International Economics published by John Wiley \& Sons Ltd 
markups (Goldberg, Khandelwal, Pavcnik, \& De Loecker, 2016) and firm decision over higher quality production (Chisik, 2012), leading to a positive impact on prices. Moreover, whereas tariffs capture an important part of the effect of trade agreements on prices, other mechanisms have been suggested by the literature, such as changes in the regulations and investment rules between members (see Baier \& Bergstrand, 2007; Ossa, 2016). ${ }^{3}$ Hence, the net effect on export prices is a priori unclear.

This paper conducts a comprehensive analysis of world trade flows at the product level to investigate the reaction of export prices to membership in the WTO and/or in PTAs and highlights a mechanism to explain the results. One important advantage of our approach is the use of highly disaggregated FOB (free on board) export price data from BACI (international trade database), which is particularly suitable for the analysis of prices, as it is the unique database that provides consistent values at the world and product level. ${ }^{4}$

Using 16 years of data with roughly 125 million observations for all countries and all manufacturing traded products, we uncover new stylized facts. First, we show that a country's membership in the WTO and/or in a PTA is associated with an increase in export prices of differentiated goods, whereas for homogeneous goods the effect is not robust and almost never significant. For the WTO, we show that the effect is captured by the countries that were subject to rigorous WTO accession procedures and not to accession under Article XXVI 5(c). ${ }^{5}$ Moreover, for intermediate goods, we show that the membership effect is only significant when the importer joins the WTO.

Second, we go beyond the analysis of membership in PTAs as a binary variable. Using a newly released dataset on the different provisions negotiated in an PTA, we investigate the importance of the depth of the agreement. We find that the effect of the depth on prices is not significant, but that individual provisions have distinct effects on prices. In particular, we find that PTAs with provisions related to investment are associated with higher export prices.

Although the aggregate data at the product level hides important composition effects (we discuss composition effects in the next section), our main results constitute evidence consistent with models that relate trade liberalization to innovation, product quality and endogenous markups. In particular, the positive effect on prices of differentiated goods (which have scope for quality differentiation) and the fact that only importers respond in the case of intermediate goods are consistent with a model in which the quality of inputs increases following trade liberalization (see Fan et al., 2015).

Concerning the second stylized fact, the positive price effect for PTAs with provisions related to investment is likely associated with quality upgrading. As discussed by Amiti and Khandelwal (2013), quality upgrading is one important element of investments in research and technology. In Amiti and Khandelwal (2013), for firms close to the technology frontier (measured by the degree of quality differentiation), the increase in competition following trade liberalization can increase the incentives to invest and innovate. ${ }^{6}$ Using product-level data on exports to the United States, they show that for firms selling high-quality products, low import tariffs promote investment and quality upgrading. Empirical evidence in Bustos (2011) shows that trade liberalization leads to more investment in innovation.

The effect of trade liberalization on prices was a priori unclear. On the one hand, we could have expected a negative effect of liberalization on prices. Following heterogeneous firms, models, aggregate productivity rises as resources are reallocated towards more productive firms (e.g., Melitz, 2003; Pavcnik, 2002). Hence, when trade barriers fall, input prices decrease, such that firms relying on intermediate inputs face lower marginal costs and charge lower export prices. ${ }^{7}$ On the other hand, the literature has shown at least two mechanisms by which lower trade barriers promote innovation and access to better inputs, which leads to quality upgrading and higher prices. Amiti and Khandelwal (2013) show that lower import tariffs promote quality upgrading for products close to the technology frontier, as it increases import competition. Fan et al. (2015) show that lower import tariffs following China's WTO membership are associated with higher export prices, as exporters gain access to higher 
quality inputs. Finally, a literature on trade disputes has shown a positive relation between trade agreements and the decision over higher quality production. For instance, Chisik (2012) provides a theoretical framework in which firms inefficiently choose lower levels of quality production when harmful trade disputes are more common. In this framework, deeper trade relationships coming from an environment of more transparency and macroeconomic stability affect the production of higher quality. ${ }^{8}$

Our empirical results suggest that, for differentiated goods, the positive price effect dominates the cost effect. Moreover, as expected, prices of homogeneous goods are by large unaffected. ${ }^{9}$ Although we do not draw direct policy implications, our results indicate that, if we consider only the costreducing effect of trade agreements and disregard innovation and quality upgrading following trade liberalization, the welfare effects from trade agreements might be wrongly estimated.

We conduct several robustness checks. First, we exploit information on the time gap between WTO application and accession. Second, we investigate the possibility that PTAs have delayed effects on prices. Third, we check the residuals of the regressions on prices for new members (four years before WTO or PTA membership) and a control group (referring to non-members and old members). We show that prior to accession, the price behavior of the two groups is very similar. Finally, we exploit heterogeneous effects of trade agreements for countries that joined the WTO under Article XXVI 5(c) in comparison with countries that were subject to rigorous accession procedures. We show that the effect of membership on prices comes entirely from countries that committed to trade policy.

\section{2 | RELATED LITERATURE}

Our paper offers a first attempt to measure the effect of trade agreements on FOB export prices at the world and product level. We also disentangle the effects of different provisions within PTAs on prices. However, the data we use at the product level hides substantial composition effects. The price response to trade liberalization might reflect quality upgrading within the firm as well as changes in the share of sales across firms within product categories. One example of a paper that investigates firm responses and composition effects is Fan et al. (2015). They show that lower import tariffs induce Chinese firms to upgrade quality and raise export prices of differentiated goods, whereas this effect is lower or nonexistent for homogeneous goods. ${ }^{10}$

Moreover, an additional channel that explains changes in prices is the incomplete pass-through following trade agreements (see Goldberg \& Pavcnik, 2016). As we discuss in Section 4.2, the price effect we observe could in part reflect changes in markups following trade liberalization, besides product quality. However, as in most of the literature, ${ }^{11}$ it is beyond the scope of this paper to disentangle the quality effect from changes in markups. In particular, because changes in markups tend to be higher for high-quality goods.

Nonetheless, by uncovering new stylized facts, our results uncover the direction of price effects and highlight the importance of product quality and further channels to explain trade prices.

Finally, our paper is related to Breinlich, Dhingra, and Berlingier (2018), who estimate the welfare effect of FTAs for countries within the European Union (EU). Using aggregate data from Comtrade, they provide a detailed analysis of the decomposition of welfare effects in the EU into variety gains, quality, and lower prices. We are rather interested in the price effects of membership in the WTO and PTAs for different types of goods, as well as in the importance of the different provisions within an agreement. For our research question, one advantage is the use of BACI data to calculate trade prices (see note 4 and data section).

Moreover, whereas Breinlich et al. (2018) focus on welfare effects within EU countries, we investigate price effects for world export flows including developed and developing countries. This might 
be important in particular for the quality channel. As discussed in Goldberg and Pavcnik (2016), "developing countries are still substantially less liberalized than developed countries, and the role of international trade in their growth and development remains one of the most interesting and policyrelevant questions".

\section{3 | DATA AND EMPIRICAL DESIGN}

\subsection{Data}

We use data on export flows at the six-digit HS (Harmonized System) level over the period 1995 to 2014 from BACI, which is based on the Commodities Trade Statistics database (Comtrade). Gaulier and Zignano (2010) use the Comtrade data to construct the BACI dataset with some modifications that make it especially suited to analyze trade prices (Gaulier \& Zignano, 2010). They point out that trade flows in the Comtrade dataset can be reported in four different ways: (i) the exporter reports the tradeflow in FOB values; (ii) the importer reports the tradeflow in CIF (cost, insurance, freight) values; (iii) both trade partners report the trade flow; or (iv) none of the countries reports the trade flow. BACI, in contrast, provides consistent values at the world and product level. ${ }^{12}$

The six-digit HS classification distinguishes more than 5,000 different products and covers the years 1995 to 2014 and 250 countries and territories. Because of the large number of observations, we create 4-year averages of the time-dependent variables, such that the final data used in the paper contains five time periods and roughly 33 million observations. Export prices are proxied by unit values, as described in detail in the Data Appendix.

Data for the explanatory variables of interest-WTO membership and membership in a PTAstem from two different sources. Michael Tomz provides data for WTO membership until 2001 on his website (Tomz, Goldstein, \& Rivers, 2007), which are used to analyze the impact of GATT/WTO membership on trade (see details in the Data Appendix). We complete the dataset until the year 2014 using information from the official WTO website (WTO, 2016). For each country, we create a dummy variable that is one if a country has joined the WTO in the period and zero otherwise, and use further information in the robustness checks. The bilateral variable for $\mathrm{WTO}\left(\mathrm{WTO}_{i j \tau}\right)$ takes on values of zero, one and two; zero when neither $i$ nor $j$ were part of the WTO in period $\tau$, one when one of the two is a member, and two when both are members. A detailed description is provided in the Data Appendix.

Besides GATT/WTO membership, we investigate the price effect of membership in PTAs. The new Design of Trade Agreements (Desta) database constructed by Dür, Baccini, and Elsig (2014) provides information on PTAs. We include a dummy that indicates if a PTA exists as well as a depth measure. The Appendix contains further information on how we calculate the PTA variables. We use a depth measure that counts the number of provisions in certain areas (tariff reduction, intellectual property rights, procurements, standards, services, investments, and competition) that are covered by an agreement. Hence, this depth measure ranges from zero (if a PTA exists but none of the provisions is covered, e.g., Protocol on Trade Negotiations) to seven (e.g., NAFTA—North American Free Trade Agreement). If the same country pair is a member in multiple agreements, we include the agreement with the greatest depth value.

The two maps (Figures 1 and 2) present a cross-country comparison of PTAs in the 5th time period, which corresponds to the years between 2011 and 2014. Figure 1 shows the mean depth of all PTA agreements for every single exporter in period 5-for every exporter in the sample, we calculate the mean depth of the PTAs in which the country is a member. It depicts that on average deeper PTAs are negotiated with countries in North and Central America, Europe, and East Asia, whereas PTAs with countries in Africa and Central Asia seem on average rather shallow. ${ }^{13}$ In the Appendix Figure A1 


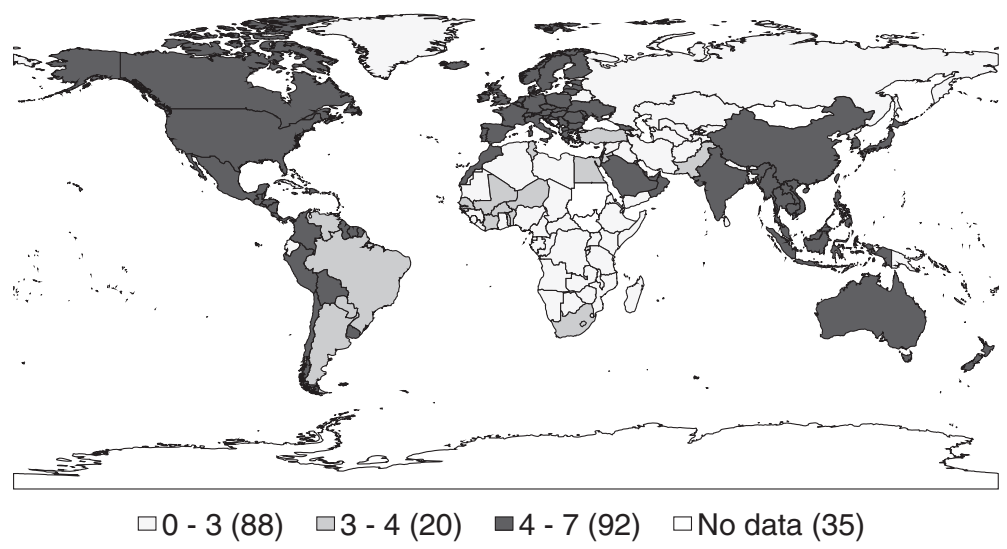

F IG URE 1 Depth of PTAs, 2011-2014

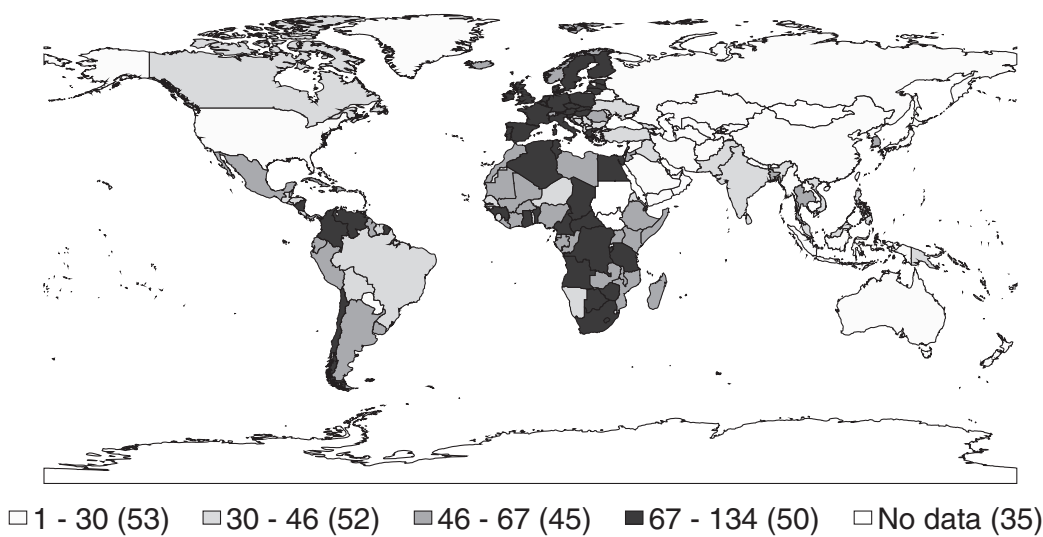

F I G U R E 2 Number of partner countries in PTAs, 2011-2014

we exploit changes over time using the difference between the last (2011-2014) and the first (19951998) period. On average for the exporter, we observe an increase in the depth measure for many countries, in particular in several Eastern European and South American countries. Although the map in differences provides an interesting contrast to Table 1, the depth measure shown in Figure A1 is less informative than Tables 1 and 3 because of the high level of aggregation. ${ }^{14}$

The second map (Figure 2) shows the average number of partner countries of each exporter, that is, the average number of countries that have a common agreement with a particular exporter. Countries in Europe and Africa have the highest average number of partner countries. While the high number of partner countries for Europe is of little surprise, the number of partner countries in Africa is mainly driven by some PTAs with many members such as the African Economic Community that alone has 51 members and covers two provisions. In the Appendix Figure A2 we exploit changes over time in the average number of partners, using the difference between the last (2011-2014) and the first (1995-1998) period.

Data for the other explanatory variables, real GDP and tariffs, come from the Penn World Table database, version 8.1 (Feenstra, Inklaar, \& Timmer, 2015) and the World Integrated Trade Solution (WITS) database (World Bank, 2016), respectively. In the Appendix we explain the transformations made to construct the tariff data. 
TAB LE 1 Explanatory variables over time

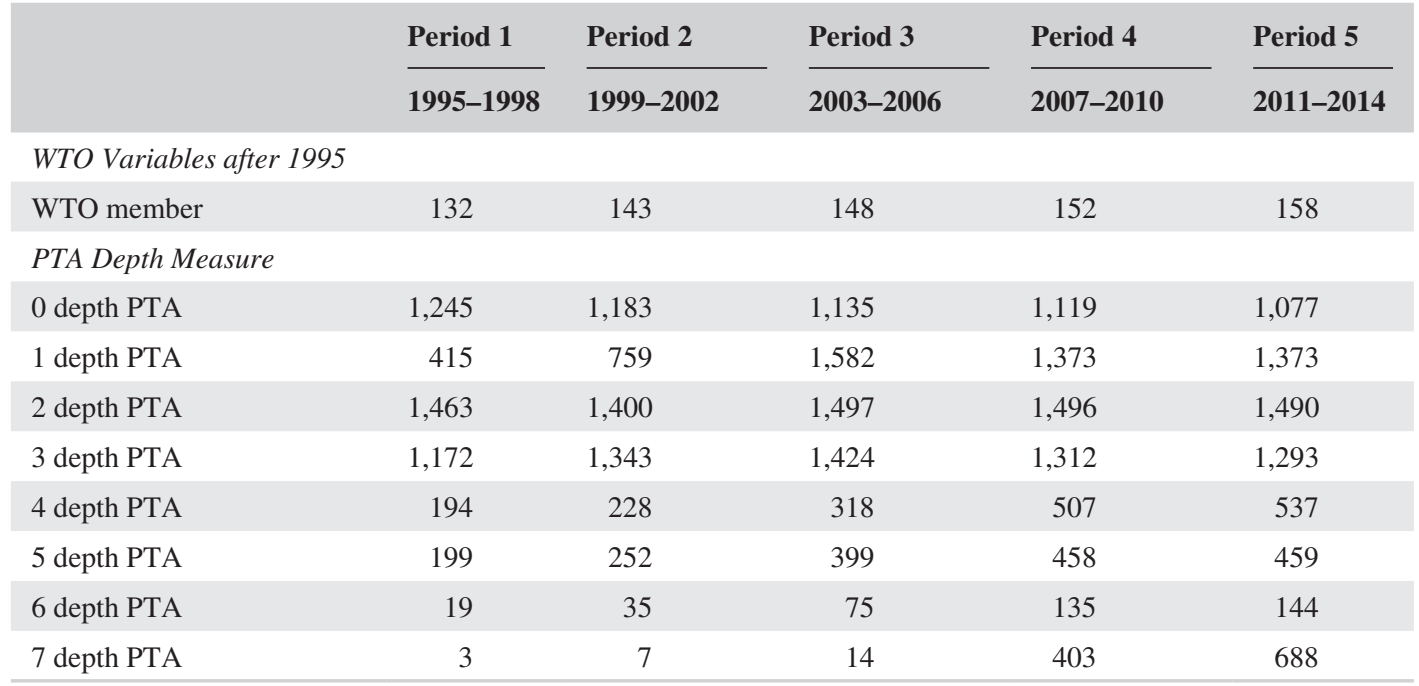

Note: Change of explanatory variables over time. Unit of variation for WTO, countries; unit of variation for PTAs, country pairs. The depth measures reflect the depth of a shared agreement ranging from zero to seven. Each time period consists of 4 years. The difference in WTO members between time period 5 and 1 does not equal 32 as in the Appendix table since six countries joined the WTO in the first time period.

TA B LE 2 WTO accessions between 1995 and 2014

\begin{tabular}{|llll|}
\hline Accession country & Accession year & Accession country & Accession year \\
\hline Albania & 2000 & Armenia & 2003 \\
\hline Bulgaria & 1996 & Cambodia & 2004 \\
\hline Cape Verde & 2008 & China & 2001 \\
\hline Congo, Democratic Republic of & 1997 & Croatia & 2000 \\
\hline Ecuador & 1996 & Estonia & 1999 \\
\hline Georgia & 2000 & Jordan & 2000 \\
\hline Kyrgyzstan & 1998 & Laos & 2013 \\
\hline Latvia & 1999 & Lithuania & 2001 \\
\hline Taiwan & 2002 & Mongolia & 1997 \\
\hline Moldova, Republic of & 2001 & Oman & 2000 \\
\hline Nepal & 2004 & Vanuatu & 2012 \\
\hline Panama & 1997 & Russian Federation & 2012 \\
\hline Saudi Arabia & 2005 & Viet Nam & 2007 \\
\hline Tajikistan & 2013 & Tonga & 2007 \\
\hline Ukraine & 2008 & Macedonia** & 2003 \\
\hline Samoa & 2012 & Yemen & 2014 \\
\hline
\end{tabular}

*Laos: Lao People's Democratic Republic; **Macedonia: The Former Yugoslav Republic of Macedonia.

Table 1 shows how the main explanatory variables-WTO membership and the depth measures for PTAs-evolve over the observed time period 1995 to 2014.

The first variable in Table 1 counts the number of WTO members over time. The list of countries that became members of WTO in every year is shown in Table 2. 
TA B LE 3 Number of different provisions over time

\begin{tabular}{|c|c|c|c|c|c|}
\hline & Period 1 & Period 2 & Period 3 & Period 4 & Period 5 \\
\hline & 1995-1998 & 1999-2002 & 2003-2006 & $2007-2010$ & 2011-2014 \\
\hline Competition & 1,309 & 1,390 & 1,667 & 2,152 & 2,475 \\
\hline Full tariff red. & 2,610 & 2,861 & 3,338 & 4,084 & 4,408 \\
\hline Investments & 1,261 & 1,309 & 1654 & 2,103 & 2,427 \\
\hline IPRS & 41 & 83 & 153 & 598 & 898 \\
\hline Procurement & 167 & 260 & 386 & 910 & 1,198 \\
\hline Services & 1,351 & 1,514 & 1823 & 2,366 & 2,663 \\
\hline Standards & 2,241 & 3644 & 4,821 & 5,088 & 5,387 \\
\hline
\end{tabular}

Note: Number of provisions per country pair in different time periods. For example, in time period 11,309 country pairs were members of a PTA that included a provision on competition.

Abbreviations: IPRS, Intellectual property rights.

The following variables in Table 1 describe the depth of the PTA. We count the country pairs that are members of a PTA with a certain depth measure at a certain time; for example, in time period 1 (1995-1998) 1,172 country pairs were members of a PTA with depth measure 3. A common pattern that we observe is that the number of country pairs that are members of "deeper" PTAs increases over time. The number of country pairs with "shallow" PTAs increases until period 3 and declines slightly afterwards. Only the number of country pairs with the most "shallow" PTA consistently declines. To better describe the importance and heterogeneity of PTAs in terms of the provisions, Table 3 shows how many country pairs are governed by the single provisions. For instance, in the first period 1,309 country pairs were members of a PTA that included a provision on competition.

The description of all variables and summary statistics are shown in Table A2.

Figure 3 plots a further pattern in the data. We show the quantity traded both before and after WTO membership for products in different export price categories. We divide products into tertiles within each industry, based on price categories according to their export prices in the period before a change in WTO status. To make products comparable, quantities are standardized to unity in the before period, and the tertiles are created within every two-digit industry. The figure shows that the trade volume increases for all price categories following WTO membership. This general result could be driven by a common time trend. However, it is interesting that the traded quantities of products with an export price in the highest tertile in the before period increase the most, whereas products with prices in the lowest tertile the least. Hence, the increase in prices that we observe in our empirical analysis is likely not due to lower sales. One plausible explanation for the increase in traded quantities of goods in the highest tertile (within an industry) is quality upgrading of goods close to the frontier (with high degree of quality differentiation). As shown by Amiti and Khandelwal (2013), by increasing competition and the incentives to innovate, trade liberalization is associated with quality upgrading for products close to the world quality frontier, whereas the opposite holds for products distant from the frontier.

\subsection{Empirical design}

To investigate the reaction of trade prices to trade agreements, we start with a very simple linear specification including interacted importer-exporter-product fixed effects as well as period fixed effects, as follows:

$$
\ln p_{k i j \tau}=\beta_{0}+\beta_{1} \text { trade_agreement } i j \tau+\beta_{2} \mathbf{X}_{k i j \tau}+\delta_{\tau}+\omega_{k i j}+\epsilon_{k i j \tau}
$$




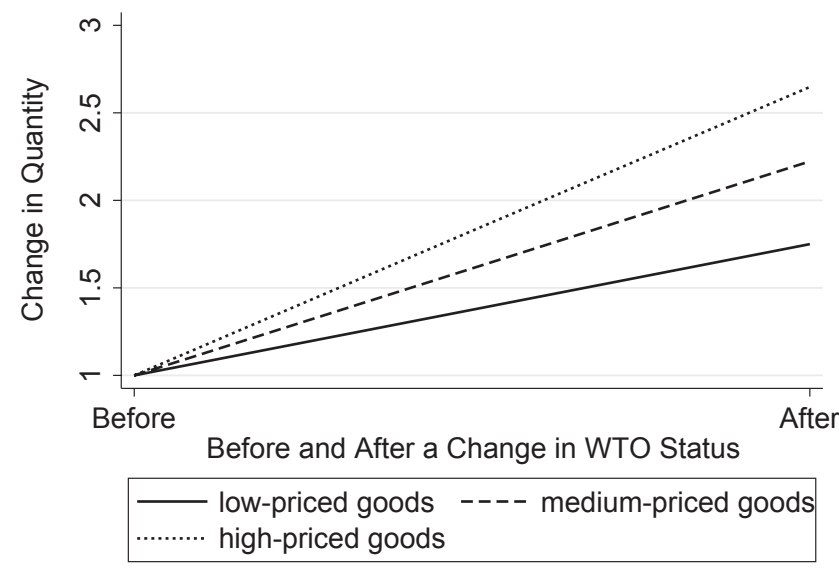

F IG U RE 3 Trade volume before and after WTO membership, for different groups of products (tertiles of prices within an industry). Note: We divide products into tertiles of export prices. The figure shows the quantity traded before and after WTO membership (quantities are standardized to unity in the before period), for the three groups of products. Trade quantities increase for all groups following WTO membership, but foremost for products in the third tertile of export prices (high-priced goods)

where $p_{k i j \tau}$ is the FOB export price measured as unit value of product $k$ exported from country $i$ to country $j$ at time $\tau$. trade_agreement $t_{i j \tau}$ either represents WTO membership $\left(\mathrm{WTO}_{i j \tau}\right)$ or membership in a PTA $\left(\mathrm{PTA}_{i j \tau}\right)$. For PTA, we create a dyadic, time-variant dummy variable. In contrast, for WTO we exploit differential effects for importer and exporter membership. We start by investigating the effect of both countries being members of WTO (WTO Both) on prices, and then go on to investigate the effect separately for importer and exporter (WTO Importer and WTO Exporter, respectively). Moreover, we also create WTO as a variable taking the values zero, one, and two depending on whether only one or both are WTO members. ${ }^{15} \omega_{k i j}$ represents interacted product-exporter-importer fixed effects and $\delta_{\tau}$ period fixed effects.

There is little theoretical guidance regarding the correct set of control variables $X_{k i j \tau}$ when it comes to the analysis of trade prices. We provide results with and without control variables. As control variables, we include the logarithmized interaction of real GDP $\left(\ln \left(\mathrm{GDP}_{i \tau} \times \mathrm{GDP}_{j \tau}\right)\right)$ and in some specifications the tariff variable averaged over 4 years $\left(\operatorname{tariff}_{i j k \tau}\right)$. In Section 5, we conduct further robustness checks including additional control variables. One of the reasons to include GDP in the baseline specification is to explore the possibility that terms of trade motivations affect our results. From standard trade policy we expect that, when the trade partner cuts tariffs and they are large (measured by country size), then the world demand for the country's exported goods increases and, in turn, so does the price of the exported products - which improves the country's terms of trade. A second reason is to relate market size to export prices: in trade models with firm heterogeneity and CES preferences, the cutoff marginal cost increases with market size of the destination country and the average export price to export from $i$ to $j$ increases in size. ${ }^{16}$ Hence, as a proxy for size, we expect that GDP of the destination country may influence trade prices. ${ }^{17}$ However, we also show that our results are not sensitive to the inclusion of GDP.

Note that, given the large number of fixed effects when we include interacted HS six-digit productimporter-exporter fixed effects and period fixed effects in a sample with over 33 million observations, it is computationally cumbersome and inefficient to include additionally importer-product-period and exporter-product-period fixed effects. In the robustness check section, we account for multilateral resistance terms in two ways, (1) using tetrads as in Hallak (2006) and Head, Mayer, and Ries (2010) and (2) we conduct the analysis in first differences, which allows for the inclusion of multilateral resistance terms. ${ }^{18}$ 
We cluster the errors in the same dimension as the fixed effects, that is, we use two-way clustering by importer-exporter-product and by time groups, which has important implications for the interpretation of the standard errors and $p$ values. We discuss clustering later in the paper. $\epsilon_{k i j \tau}$ is the error term.

In a second step, we investigate the differential effects for different types of goods and different types of trade agreements. We divide goods in homogeneous (HOM goods) and differentiated goods (DIFF goods) following Rauch (1999). In this case, we interact the variable trade_agreement $t_{i j \tau}$ with indicator variables for HOM goods and DIFF goods.

According to the literature on quality upgrading as a response to a fall in tariffs (e.g., Fan et al., 2015), we expect the positive effect of trade_agreement ${ }_{i j \tau}$ on prices to be driven by differentiated goods.

Finally, we investigate the importance of the depth of a PTA, as follows:

$$
\ln p_{k i j \tau}=\beta_{0}+\beta_{1} \mathrm{PTA}_{i j \tau}+\beta_{2} \mathrm{PTA}_{i j \tau} \times \operatorname{depth}_{i j \tau}+\delta_{\tau}+\omega_{k i j}+\epsilon_{k i j \tau}
$$

where PTA $_{i j \tau}$ is a dummy variable that indicates the presence of a PTA, as before, and depth ${ }_{i j \tau}$ indicates the number of provisions in certain areas (tariff reduction, intellectual property rights, procurements, standards, services, investments, and competition) that are covered by a PTA. The depth measure ranges from zero (if a PTA exists but none of the provisions is covered, e.g., Protocol on Trade Negotiations) to seven (e.g., NAFTA). All estimations include exporter-importer-product fixed effects.

Additionally, we disentangle the depth measure in its seven provisions to get an insight on how they affect export prices:

$$
\ln p_{k i j \tau}=\beta_{0}+\beta_{1} \mathrm{PTA}_{i j \tau}+\sum_{p=1}^{7} \beta_{p+1} \mathrm{PTA}_{i j \tau} \times \text { provision }_{i j \tau p}+\delta_{\tau}+\omega_{k i j}+\epsilon_{k i j \tau}
$$

where provision $_{i j \tau p}$ is an indicator taking one if a particular provision is covered and zero otherwise. All estimations include exporter-importer-product fixed effects.

In all results, we use two-way clustering by $i-j-k$ and by time groups (see Cameron, Gelbach, \& Miller, 2011). Besides the standard clusters by by $i-j-k$, clustering over time is crucial in the context of our paper. As shown for instance in Cao and Flach (2015), there is a negative dependence of the standard deviation of prices on WTO membership. Hence, without correction, the error term would likely be heteroskedastic.

\section{4 | EMPIRICAL RESULTS}

The first results for the effect of WTO and PTAs on prices are shown in Tables 4 and 5. The estimation strategy corresponds to Equation 1. The results include interacted six-digit product-importer-exporter fixed effects as well as time fixed effects. In robustness checks we include further groups of fixed effects to account for multilateral resistance terms. Moreover, crucial for our analysis, all results are reported using FOB export prices, that is, the prices at the port of shipment, excluding transportation costs and other costs associated with insurance and unloading.

All results in the paper are reported using 4-year averages, which yields a sample of roughly 33 million observations. Besides computational gains, taking averages also allows us to deal with issues related to serial correlation and the adjustment of standard errors (see Bertrand, Duflo, \& Mullainathan, 2004). This is important in our framework because of the three following reasons. In our paper, we deal with (1) long time series, (2) the dependent variable (price) is highly positively 
T A B LE 4 Results for WTO and PTA

\begin{tabular}{|c|c|c|c|c|c|c|}
\hline & (1) & (2) & (3) & (4) & (5) & (6) \\
\hline WTO Both & $\begin{array}{l}0.0689 * \\
(0.0275)\end{array}$ & & $\begin{array}{l}0.0366^{*} \\
(0.0139)\end{array}$ & $\begin{array}{l}0.0730 * \\
(0.0279)\end{array}$ & & $\begin{array}{l}0.0366^{*} \\
(0.0139)\end{array}$ \\
\hline $\begin{array}{l}\text { WTO Both } \times \\
\text { DIFF }\end{array}$ & & $\begin{array}{l}0.0786 * * \\
(0.0263)\end{array}$ & & & $\begin{array}{l}0.0826 * * \\
(0.0267)\end{array}$ & \\
\hline $\begin{array}{l}\text { WTO Both } \times \\
\text { HOM }\end{array}$ & & $\begin{array}{l}0.0293 \\
(0.0360)\end{array}$ & & & $\begin{array}{l}0.0336 \\
(0.0366)\end{array}$ & \\
\hline WTO Exporter & & & $\begin{array}{l}0.0590 * * \\
(0.0199)\end{array}$ & & & $\begin{array}{l}0.0672 * * \\
(0.0159)\end{array}$ \\
\hline WTO Importer & & & $\begin{array}{l}0.131 * * * \\
(0.0143)\end{array}$ & & & $\begin{array}{l}0.139 * * * \\
(0.0183)\end{array}$ \\
\hline PTA & & & $\begin{array}{l}0.0244 \\
(0.0154)\end{array}$ & & & $\begin{array}{l}0.0232 \\
(0.0159)\end{array}$ \\
\hline $\begin{array}{c}\ln \left(\mathrm{GDP}_{i \tau} \times\right. \\
\left.\mathrm{GDP}_{j \tau}\right)\end{array}$ & $\begin{array}{l}0.0206 \\
(0.0145)\end{array}$ & $\begin{array}{l}0.0207 \\
(0.0145)\end{array}$ & $\begin{array}{l}0.0183 \\
(0.0148)\end{array}$ & & & \\
\hline Observations & $33,161,901$ & $33,161,901$ & $33,161,901$ & $33,161,901$ & $33,161,901$ & $33,161,901$ \\
\hline Adjusted $R^{2}$ & 0.793 & 0.793 & 0.793 & 0.793 & 0.793 & 0.793 \\
\hline Fixed effects & $t \& i j k$ & $t \& i j k$ & $t \& i j k$ & $t \& i j k$ & $t \& i j k$ & $t \& i j k$ \\
\hline
\end{tabular}

Note: Robust standard errors are shown in parentheses.

Abbreviations: DIFF, differentiated; HOM, homogeneous.

$* * *, * *, *$ Denotes significance at the $1 \%, 5 \%$, and $10 \%$ level, respectively. Robust standard errors two-way clustered by importer-exporter-product and time groups, see Cameron et al. (2011).

serially correlated, and (3) the independent variable (trade_agreement ${ }_{i j \tau}$ ) changes little over time (WTO member or not, PTA member or not). As discussed in Bertrand et al. (2004), in this setting, these three factors reinforce each other, so that the standard error of $\beta_{1}$ in the empirical model shown in Equation 1 could understate the standard deviation of $\beta_{1}$. Hence, serial correlation is an especially important concern in our framework, in particular in a context in which prices are highly auto-correlated. Results are reported using two-way clustering at importer-exporter-product and time level, which has implications for the interpretation of the standard errors.

In Table 4 in column (1), we start by investigating the effect of both countries being members of WTO (WTO Both) on prices. Four crucial facts can be shown in Table 4. First, we show that membership of both importer and exporter in the WTO is associated with higher export prices (see column 1). Second, we show that the effect is solely driven by differentiated goods, as shown by the interaction term WTO Both $\times$ DIFF in column (2). Third, because WTO is not a bilateral variable, in column (3) we investigate the effect of WTO membership separately for importer and exporter. We show that the effect of WTO membership is heterogeneous, a feature that we will exploit later in the paper. The coefficients suggest that the effect is much larger if the importer enters WTO. Fourth, for PTA we show that the average effect on prices is not significant (see column 3). Hence, in Section 4.1 we will exploit the depth of agreements and the provisions within an agreement to investigate heterogeneous effects of PTAs. Finally, in columns (4) to (6) we show that the results are not affected by controlling or not for GDP as a proxy for market size, as the results remain highly stable.

In Table 5, we are mainly interested in exploiting the differential effects of membership across types of goods. Hence, we simplify the analysis and use WTO variable as an importer-exporter-time 
TA B LE 5 Results for WTO and PTA across types of goods

\begin{tabular}{|c|c|c|c|c|c|c|}
\hline & (1) & (2) & (3) & (4) & (5) & (6) \\
\hline \multirow[t]{2}{*}{ WTO } & $0.0697 * *$ & & & & $0.0692 * *$ & $0.0716^{*}$ \\
\hline & $(0.0236)$ & & & & $(0.0239)$ & $(0.0258)$ \\
\hline \multirow{2}{*}{$\begin{array}{l}\text { WTO } \times \text { DIFF } \\
\text { good }\end{array}$} & & $0.0792 * *$ & & & & \\
\hline & & $(0.0226)$ & & & & \\
\hline \multirow{2}{*}{$\begin{array}{l}\text { WTO } \times \text { HOM } \\
\text { good }\end{array}$} & & 0.0312 & & & & \\
\hline & & $(0.0303)$ & & & & \\
\hline \multirow[t]{2}{*}{ PTA } & & & 0.0255 & & 0.0228 & 0.0643 \\
\hline & & & $(0.0157)$ & & $(0.0154)$ & $(0.0306)$ \\
\hline \multirow{2}{*}{$\begin{array}{l}\text { PTA } \times \text { DIFF } \\
\text { good }\end{array}$} & & & & 0.0316 & & \\
\hline & & & & $(0.0192)$ & & \\
\hline \multirow{2}{*}{$\begin{array}{l}\text { PTA } \times \text { HOM } \\
\text { good }\end{array}$} & & & & 0.00239 & & \\
\hline & & & & $(0.0177)$ & & \\
\hline \multirow[t]{2}{*}{ PTA × WTO } & & & & & & -0.0212 \\
\hline & & & & & & $(0.0215)$ \\
\hline \multirow{2}{*}{$\begin{array}{c}\ln \left(\mathrm{GDP}_{i \tau} \times\right. \\
\left.\mathrm{GDP}_{j \tau}\right)\end{array}$} & 0.0174 & 0.0175 & 0.0298 & 0.0298 & 0.0182 & 0.0182 \\
\hline & $(0.0144)$ & $(0.0144)$ & $(0.0148)$ & $(0.0148)$ & $(0.0143)$ & $(0.0143)$ \\
\hline Observations & $33,161,901$ & $33,161,901$ & $33,161,901$ & $33,161,901$ & $33,161,901$ & $33,161,901$ \\
\hline Adjusted $R^{2}$ & 0.793 & 0.793 & 0.793 & 0.793 & 0.793 & 0.793 \\
\hline Fixed effects & $t \& i j k$ & $t \& i j k$ & $t \& i j k$ & $t \& i j k$ & $t \& i j k$ & $t \& i j k$ \\
\hline
\end{tabular}

Note: Robust standard errors are shown in parentheses.

Abbreviations: DIFF, differentiated; HOM, homogeneous.

$* * *, * * *$ Denotes significance at the $1 \%, 5 \%$, and $10 \%$ level, respectively. Robust standard errors two-way clustered by importer-exporter-product and time groups, see Cameron et al. (2011).

specific variable, so that we avoid the large number of interaction terms and investigate the importance of differentiated goods. The WTO variable is coded as an $i-j-t$ variable and takes the values zero, one, and two. As shown in columns (1), (3), and (5), membership in the WTO and/or in PTAs is associated with higher FOB export prices. Columns (2) and (4) show results for different types of goods. For WTO the effect is captured by differentiated goods, whereas for membership in an PTA the results are not significant. However, as we will show in further results in the paper, for PTAs the effect depends on the depth and on the provisions within a trade agreement.

In column (6), we include an interaction term between the WTO and the PTA variable to test whether there is a complementarity between the WTO and the PTA variable. Subramanian and Wei (2007) suggest for trade volumes that, conditioning on having a common FTA, WTO membership does not further increase trade. The insignificant coefficient for the interaction term in column (6) indicates independence of the WTO and PTA variable, as WTO membership does not change export prices any further for countries that are already in a common PTA.

We conduct three robustness checks to the results reported in Tables 4 and 5: (a) control for tariffs, (b) exclude GDP, and (c) estimate with alternative clustering level.

In Table A6 in the Appendix, we include tariffs as a control variable. We lose many observations because of missing tariff data. Controlling for PTA and WTO membership, higher tariffs are 
associated with higher prices. Most importantly, most of the results for WTO and PTA remain stable. For PTA, the coefficient is more precisely estimated in column (6) once we control for tariffs.

The results in Table A6 controlling for tariffs may suggest that, although tariffs capture an important part of the effect of trade agreements on prices, other channels may explain the price variation (see, for instance, Baier and Bergstrand [2007] and Ossa [2016] for a discussion on the reaction to trade agreements). The results also suggest that it is important to investigate trade agreements in a finer level of detail, which we do in the next section.

In Table A5 in the Appendix, we exclude the GDP variable, as there is little theoretical guidance regarding the inclusion of GDP in the empirical specification. As shown in Table A5, our coefficients of interest remain very similar, though are always a bit larger in terms of magnitudes.

Finally, in Table A7 we estimate the effect with two-way clustering at importer-exporter and year level instead of importer-exporter-product and year level. Because trade agreements (our regressor of interest) do not vary by product, clustering at the importer-exporter-product level could induce correlation of the error across products within a country pair. We show that the standard errors are very similar in both cases. ${ }^{19}$

\section{1 | The depth of the agreement and its provisions}

According to the recently released Desta dataset that we use in this paper, one can divide the provisions of an PTA in seven groups with tariffs representing one of them. We take advantage of this level of detail and investigate the importance of the depth of a PTA as well as of the different provisions within an agreement.

The results shown in Table 6 (column 1) reveal that the depth of the agreement has no effect on prices, as shown by the interaction term PTA $\times$ depth. However, the results differ when we conduct the analysis for different groups of countries, that is, for trade among high-income countries (high inc group) and trade among low-income countries (low inc group), as shown in columns (2) and (3). Whereas for trade among low-income countries the PTA dummy captures the whole effect on prices, for trade among high-income countries the depth of the agreement captures the whole effect. Hence, to better understand the importance of the depth measure, we investigate its different provisions using interaction terms $\mathrm{PTA}_{i j \tau} \times$ provision $_{i j \tau p}$ for all seven provisions, as shown in columns (4) to (6).

The most interesting result in column (4) refers to the positive relation between investment provisions and prices. This is particularly true for trade among developing countries, as shown in column (5). For trade among high-income countries (column 6), the positive effect on trade prices is rather captured by intellectual property rights (IPRS) and full tariff reductions. It is interesting to note that, besides the tariff mechanism, which is consistent with Fan et al. (2015), investments and property rights exert a positive effect on prices. These results can be reconciled with Amiti and Khandelwal (2013), who provide evidence of quality upgrading following trade liberalization and relate their results to distance to the frontier models. According to these models, the increase in competition following trade liberalization increases the incentives to invest and innovate for firms close to the technology frontier. ${ }^{20}$ Aghion, Blundell, Gric, Howitt, and Prantl (2009) refer to this as the escape-entry effect, as innovation enables incumbent firms to escape from the threat of competition. Note also that in column 5, as in column 2, the level effect of the PTA dummy remains with a positive effect on prices, which suggests that for trade among low-income countries, membership in the agreement (despite the provisions) has already a positive effect on prices, whereas the same is not true for trade among high-income countries (see columns 3 and 6). 


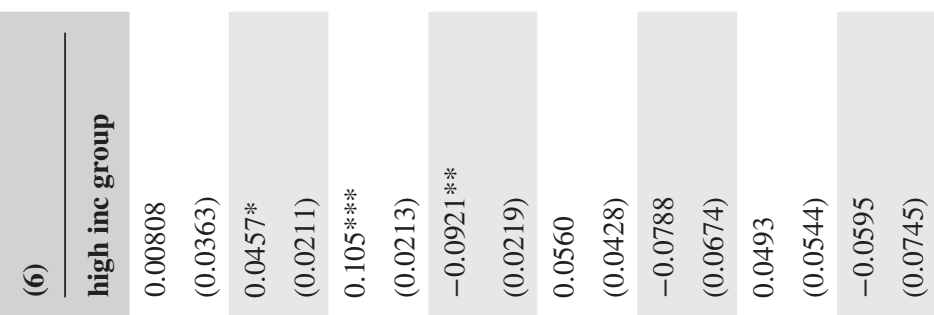

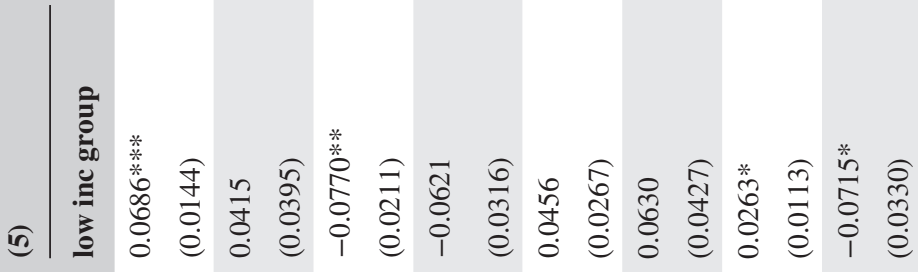

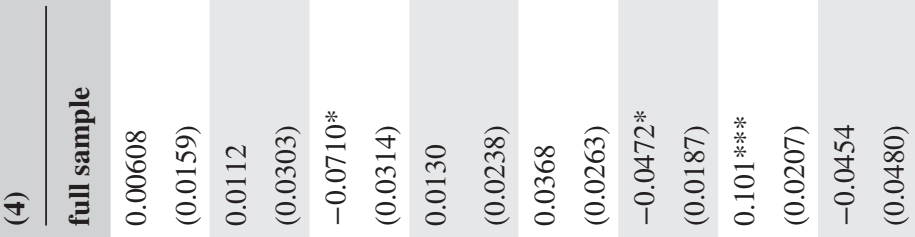

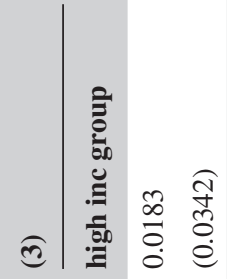

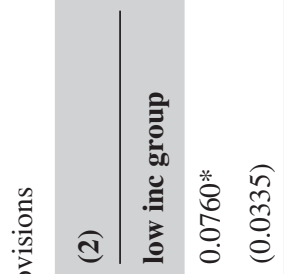

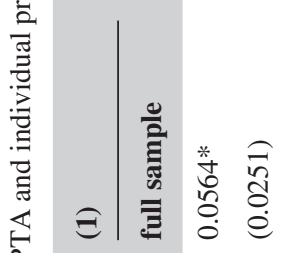

त

若

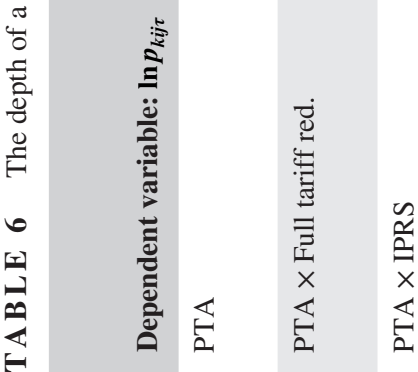

돈

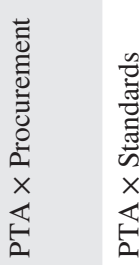

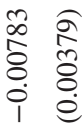
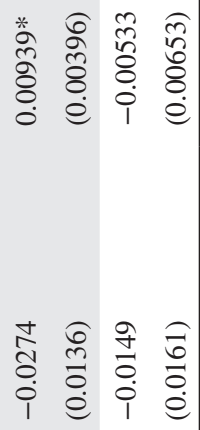


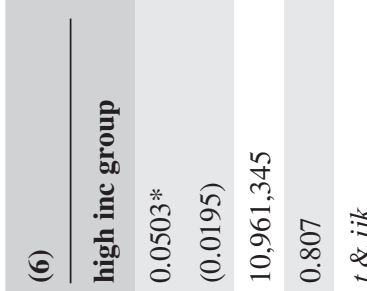

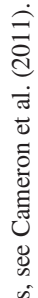

(1)

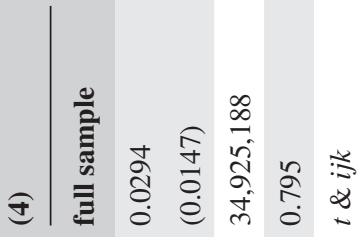

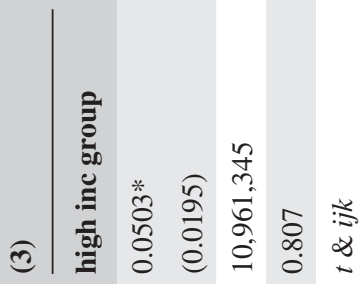

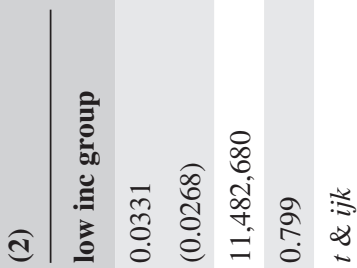

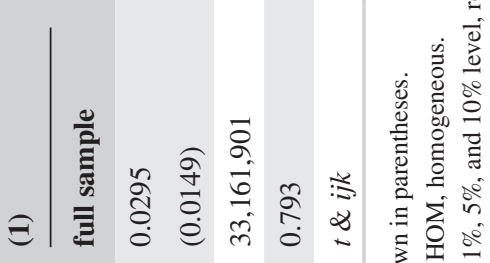

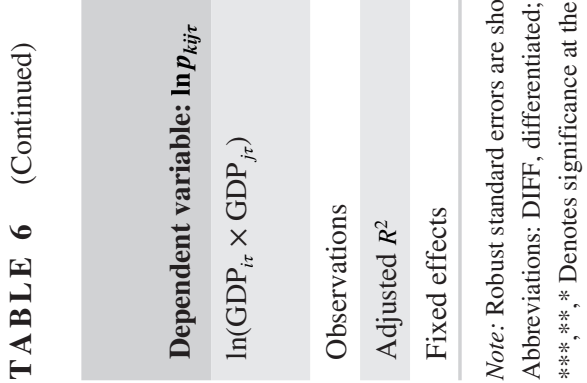




\section{2 | Exporter and importer WTO accessions}

In Table 4, we provide results separately for exporter and importer accession, also adding an interaction term to investigate whether the result is magnified in case both countries are WTO members. To better understand what drives the results for different types of goods, in this section we evaluate separately the effect of importer and exporter accession for differentiated vs. homogeneous goods. The results shown in Table 7 reinforce the hypothesis of the quality mechanism for differentiated goods, but also suggests that the incomplete pass-through might explain part of the results.

In line with the quality upgrading explanation suggested by Fan et al. (2015), we find that, for exporter accession, the positive effect on prices is solely captured by differentiated goods. The results remain robust when we control for tariffs and membership in PTAs. However, they are less precisely estimated when we control for both tariffs and PTA. In this case, the positive effect on prices is captured by the PTA dummy.

For importer accession, we find a smaller difference between homogeneous and differentiated goods. The larger effect for differentiated goods (in comparison with homogeneous goods) could be interpreted along the lines of Kugler and Verhoogen (2012), who suggest that, to produce higher quality, the importer has to use more expensive intermediate goods, implying higher prices. To investigate this mechanism in more detail, we conduct an analysis only for intermediate goods in the next section.

Another explanation for the positive effect for both types of goods could be the pass-through: as tariffs in the importing country decrease, exporters have some scope for a price increase, given that the import market is not perfectly competitive. Thus, consumer prices would not decrease by the same amount as the decrease in import tariffs. In other words, the price decline following a decrease in input tariffs might be small as firms might react by raising their markups (see Goldberg et al., 2016). ${ }^{21}$ Along with the pass-through hypothesis, one explanation for the slightly smaller coefficient for homogeneous products could be that markets for homogeneous products are more competitive and hence firms that export homogeneous products cannot set as high of a markup as they can for differentiated products.

\subsection{Intermediate goods}

To better understand the theoretical mechanism proposed by Fan et al. (2015), according to which the quality of the imported inputs increases following trade liberalization, we investigate the effect for intermediate goods. Fan et al. (2015) also provide empirical evidence for Chinese firms that the fall in tariffs following membership in the WTO increases export prices, as it leads to imports of higher quality goods. In line with their results, we show in Table 8 that, for intermediate goods, the positive effect of WTO membership on prices is driven solely by importer accession. For PTAs, which are always bilateral agreements, the effect is not significant. ${ }^{22}$ As in former results, the results are robust to the inclusion of interacted importer-exporter-product fixed effects as well as time fixed effects.

\section{5 | ROBUSTNESS CHECKS}

\section{1 | Tetrads and multilateral resistance terms}

In our baseline results, the estimation is conducted using interacted product-importer-exporter fixed effects and period fixed effects. ${ }^{23}$ Adding further dimensions of fixed effects for data with this dimensionality has two drawbacks: it is computationally cumbersome and more degrees of freedom are lost. Hence, in this case, one standard way to account for multilateral resistance terms is the use of tetrads, which was developed for the analysis of trade flows. See, for instance, Hallak (2006) and Head et al. 
TA B L E 7 Exporter and importer WTO accession

\begin{tabular}{|c|c|c|c|c|}
\hline Dependent variable: $\ln p_{k i j \tau}$ & (1) & (2) & (3) & (4) \\
\hline \multirow[t]{2}{*}{ WTO Exporter $\times$ DIFF. Good } & $0.049^{*}$ & $0.046^{*}$ & $0.045^{*}$ & 0.040 \\
\hline & $(0.020)$ & $(0.019)$ & $(0.020)$ & $(0.019)$ \\
\hline \multirow[t]{2}{*}{ WTO Exporter $\times$ HOM. Good } & -0.047 & -0.062 & -0.053 & -0.074 \\
\hline & $(0.051)$ & $(0.062)$ & $(0.051)$ & $(0.064)$ \\
\hline \multirow[t]{2}{*}{ WTO Importer $\times$ DIFF. Good } & $0.102^{* *}$ & $0.104 * *$ & $0.100^{* *}$ & $0.102^{* *}$ \\
\hline & $(0.029)$ & $(0.033)$ & $(0.028)$ & $(0.033)$ \\
\hline \multirow[t]{2}{*}{ WTO Importer $\times$ HOM. Good } & $0.087^{* *}$ & $0.095^{*}$ & $0.086^{* *}$ & $0.092 *$ \\
\hline & $(0.030)$ & $(0.036)$ & $(0.029)$ & $(0.035)$ \\
\hline \multirow[t]{2}{*}{ tariff $_{i j k t} \times$ DIFF. Good } & & 0.001 & & 0.001 \\
\hline & & $(0.001)$ & & $(0.001)$ \\
\hline \multirow[t]{2}{*}{$\operatorname{tariff}_{i j k t} \times$ HOM. Good } & & 0.002 & & 0.002 \\
\hline & & $(0.002)$ & & $(0.002)$ \\
\hline \multirow[t]{2}{*}{ PTA } & & & 0.045 & $0.080^{*}$ \\
\hline & & & $(0.032)$ & $(0.032)$ \\
\hline \multirow[t]{2}{*}{ PTA Depth $\times$ DIFF. Good } & & & -0.005 & $-0.016^{*}$ \\
\hline & & & $(0.004)$ & $(0.006)$ \\
\hline \multirow[t]{2}{*}{ PTA Depth $\times$ HOM. Good } & & & -0.008 & -0.010 \\
\hline & & & $(0.006)$ & $(0.007)$ \\
\hline \multirow[t]{2}{*}{$\ln \left(\mathrm{GDP}_{i \tau} \times \mathrm{GDP}_{j \tau}\right)$} & 0.018 & 0.015 & 0.019 & 0.015 \\
\hline & $(0.015)$ & $(0.028)$ & $(0.015)$ & $(0.028)$ \\
\hline Observations & 33,162 & 24,410 & 33,051 & 24,315 \\
\hline RMSE & 0.959 & 0.946 & 0.959 & 0.946 \\
\hline Adjusted $R^{2}$ & 0.716 & 0.714 & 0.716 & 0.714 \\
\hline Fixed effects & $t \& i j k$ & $t \& i j k$ & $t \& i j k$ & $t \& i j k$ \\
\hline
\end{tabular}

Note: Robust standard errors are shown in parentheses.

Abbreviations: DIFF, differentiated; HOM, homogeneous.

$* * *, * * *$ Denotes significance at the $1 \%, 5 \%$, and $10 \%$ level, respectively. Robust standard errors two-way clustered by importerexporter-product and time groups, see Cameron et al. (2011).

(2010) for an analysis using tetrads, and Anderson and Van Wincoop (2003) for a discussion on multilateral resistance terms. Similar to the analysis of trade flows, the advantage of tetrads in the context of our data is that we can additionally account for time-varying importer-period and exporter-period fixed effects.

We follow Head et al. (2010) and use the United States as the reference importer and Germany as the reference exporter country. ${ }^{24}$ Hence, the new variables can be shown as follows:

$$
X_{\text {newVariable }}=\frac{X_{i, j} / X_{i, U S}}{X_{G E R, j} / X_{G E R, U S}}
$$

The complete procedure for the estimation of tetrads is explained in the Appendix. Transforming the left-hand side and right-hand side of our baseline equation we can show that all time-exporter and timeimporter specific variation cancels out and we estimate the following equation: 
T A B L E 8 Results for intermediate goods

\begin{tabular}{|lllll|}
$\begin{array}{l}\text { Dependent variable: } \\
\text { In } \boldsymbol{p}_{\text {kij } \tau}\end{array}$ & $\mathbf{( 1 )}$ & $\mathbf{( 2 )}$ & $\mathbf{( 3 )}$ & $\mathbf{( 4 )}$ \\
\hline WTO Exporter & -0.0473 & -0.0509 & -0.0552 & -0.0618 \\
& $(0.0529)$ & $(0.0516)$ & $(0.0594)$ & $(0.0597)$ \\
\hline WTO Importer & $0.0820^{* *}$ & $0.0804 * *$ & $0.0879 *$ & $0.0861^{*}$ \\
& $(0.0262)$ & $(0.0252)$ & $(0.0326)$ & $(0.0312)$ \\
\hline PTA & & -0.0169 & & 0.0292 \\
& & $(0.0324)$ & & $(0.0301)$ \\
\hline PTA $\times$ depth & & -0.00441 & & -0.00984 \\
& & $(0.00477)$ & & $(0.00537)$ \\
\hline tariff & & & $0.00335^{* *}$ \\
& & & $0.00336 * *$ & $(0.000970)$ \\
\hline ln $\left(\mathrm{GDP}_{i \tau} \times \mathrm{GDP}_{j \tau}\right)$ & -0.0169 & -0.0181 & -0.0290 & -0.0296 \\
& $(0.0270)$ & $(0.0273)$ & $(0.0383)$ & $(0.0386)$ \\
\hline Observations & $9,950,122$ & $9,918,925$ & $7,248,789$ & $7,221,534$ \\
\hline Adjusted $R^{2}$ & 0.808 & 0.808 & 0.815 & 0.815 \\
\hline Fixed effects & $t \& i j k$ & $t \& i j k$ & $t \& i j k$ & $t \& i j k$ \\
\hline
\end{tabular}

Note: Robust standard errors are shown in parentheses.

Abbreviations: DIFF, differentiated; HOM, homogeneous.

$* * *, * *, *$ Denotes significance at the $1 \%, 5 \%$, and $10 \%$ level, respectively. Robust standard errors two-way clustered by importer-exporter-product and time groups, see Cameron et al. (2011).

$$
\ln \left(\overline{\operatorname{price}}_{k i j \tau}\right)=\beta_{0}+\beta_{1} \overline{W T O}_{i j \tau}+\bar{\omega}_{k i j}+\bar{\epsilon}_{k i j \tau}
$$

where variables with a bar represent transformed variables according to Equation 4. For example, the decomposition of the error term into its four elements gives $\bar{\epsilon}_{k i j \tau}=\epsilon_{k i j \tau}-\epsilon_{k i, U S \tau}-\epsilon_{k, G E R, j \tau}+\epsilon_{k, G E R, U S \tau}$. We estimate Equation 5 with time fixed effects to capture the last element of the transformed error term and with importer-exporter-product fixed effects to absorb unobserved heterogeneity in the importerexporter-product dimension, $\bar{\omega}_{k i j}$. Additional to the time and importer-exporter-product dimension, we cluster over importer-time and exporter-time groups as Head et al. (2010) show that error terms are no longer independently distributed if one uses the tetrad method because parts of the (now) composite error reoccur.

The variable WTO Both attempts to capture the effect of both countries being members of the WTO compared with a base category where either one country or no country is a member of the WTO. Hence, the results for the estimations of Equation 5 are not directly comparable with the results shown in Table 5, where the WTO variable takes the values 0,1 , and 2 . However, the results can be easily compared with Table 4, which reports results for WTO Both.

We also use China as a reference exporter to check the validity of the tetrad method. We have chosen China as an alternative reference exporter for the same reason we have chosen Germany: we can reference as many traded products as possible. China's WTO status changes for some observations in the observed time period. Hence, the transformed export price could not only change because nonreference countries join the WTO, but also because China's WTO accession could influence the Chinese reference price. ${ }^{25}$ Even though the results for China are not directly comparable with the results for 
Germany, they follow a similar pattern. We conduct the same analysis for Japan and find similar results in comparison with Germany as baseline.

Table 9 presents the results for the tetrad method. Similar to Head et al. (2010), we find that the choice of the reference exporter matters for the results. If we compare the results in Table 9 with the results from Table 4, we see that the coefficients on the WTO measure are generally larger in the tetrad specification. Assuming that this increase is not entirely attributable to the different WTO variable in the baseline specification, this would mean that the tetrad method is able to capture unobserved heterogeneity in the importer-time and/or exporter-time dimension. This unobserved heterogeneity would be negatively correlated with the WTO variable in the baseline regression.

The results shown in columns (2) to (5) confirm our earlier results. As in the baseline results, the tetrads reveal that WTO accession is associated with a higher increase in the export price of differentiated products compared with homogeneous products. Moreover, the WTO coefficients stay unaffected if we additionally control for membership in a PTA, which is another sign that the WTO and the PTA variable are conditionally independent. The results using China as the second reference exporter do not change our interpretation.

\subsection{Empirical analysis using first differences}

Besides using tetrads to account for multilateral resistance terms, we also estimate the model taking first differences from Equation 1. In this way, we only need to include interacted importer-productyear and exporter-product-year fixed effects in the empirical specification, as follows:

$$
\Delta \ln p_{k i j \tau}=\beta_{0}+\beta_{1} \Delta \text { trade_agreement } t_{i j \tau}+\beta_{2} \Delta \mathbf{X}_{k i j \tau}+\rho_{i k t}+v_{j k t}+\epsilon_{k i j \tau}
$$

where $\Delta p_{k i j \tau}$ is the change in FOB export price between two periods $\tau$ and $\tau-1 . \rho_{i k t}$ and $v_{j k t}$ are importerproduct-year and exporter-product-year fixed effects and, hence, they account for multilateral resistance terms. Errors are clustered by importer-exporter-product and time groups, as in previous estimations. A disadvantage of this empirical strategy is that we cannot separately identify $W T O_{i}$ and $W T O_{j}$.

T A B L E 9 Tetrad results-Robustness checks I

\begin{tabular}{|c|c|c|c|c|c|c|}
\hline & \multicolumn{3}{|l|}{ GER-US } & \multicolumn{3}{|l|}{ CHN-US } \\
\hline & (1) & (2) & (3) & (4) & (5) & (6) \\
\hline \multirow{2}{*}{$\begin{array}{l}\text { WTO Both } \times \\
\text { DIFF good }\end{array}$} & & $0.194 *$ & $0.193^{*}$ & & $0.337 * * *$ & $0.333 * * *$ \\
\hline & & $(0.073)$ & $(0.073)$ & & $(0.040)$ & (0.039) \\
\hline \multirow[t]{2}{*}{ WTO Both } & $0.343 * *$ & $0.185 * * *$ & $0.186 * * *$ & $0.226 * * *$ & $-0.058 *$ & $-0.057 *$ \\
\hline & $(0.087)$ & $(0.033)$ & $(0.033)$ & $(0.020)$ & $(0.023)$ & $(0.024)$ \\
\hline \multirow[t]{2}{*}{ PTA } & & & 0.021 & & & $0.087 * *$ \\
\hline & & & $(0.013)$ & & & $(0.026)$ \\
\hline Observations & 26,589 & 26,589 & 26,589 & 25,679 & 25,679 & 25,679 \\
\hline RMSE & 1.260 & 1.260 & 1.260 & 1.355 & 1.355 & 1.355 \\
\hline Adjusted $R^{2}$ & 0.269 & 0.269 & 0.269 & 0.281 & 0.281 & 0.282 \\
\hline
\end{tabular}

Notes: Robust standard errors are shown in parentheses. Absorbed heterogeneity in the time-exporter and time-importer dimension via tetrad method.

Abbreviations: DIFF, differentiated; FEs, time, importer-exporter-product; HOM, homogeneous.

$* * * * * *$ Denotes significance at the $1 \%, 5 \%$, and $10 \%$ level, respectively. Robust standard errors two-way clustered by importer-exporter-product and time groups, see Cameron et al. (2011). Number of observations in 1,000. 
To facilitate comparison with the results using tetrads and with the baseline results shown in Table 5 (column 7) (interaction term WTO Both), we estimate the model in differences using the WTO variable as WTO Both, which is one if both countries are WTO members in $\tau$.

The results shown in Table 10 reinforce our hypothesis. We find a positive effect on prices, which is captured by differentiated goods. We find similar effects in differences in comparison with Table 4 (shown by the interaction term WTO Both). The results using tetrads are larger but, as discussed in the previous section, they are sensitive to the choice of the reference exporter. In column (3), we also show a positive effect of PTA on prices. Moreover, if we additionally control for membership in a PTA, the coefficients on WTO remain very similar, which is a sign that the WTO and the PTA variable are conditionally independent.

\subsection{Official versus unofficial members}

We investigate the robustness of the results when using an alternative classification of WTO membership following Tomz et al. (2007). Tomz et al. (2007) distinguish various ways by which territories joined the GATT/WTO. We take advantage of the richness of WTO accession categories by changing the WTO membership definition. Tomz et al. (2007) point out that colonies and provisional members are officially not WTO members, but have largely the same rights as official members. They also consider these non-members in their analysis and find, contrary to Rose (2004a), a trade promoting effect of WTO membership using the same approach as Rose (2004a).

Following their idea, we treat colonies as WTO members. In the data, no country is a provisional member. We do not include de facto members because the WTO, contrary to the GATT, no longer accepts this status. ${ }^{26}$ In contrast, territories and countries that joined the GATT by evoking Article XXVI:5(c) were not obliged to conduct far-reaching, structural reforms and are thus arguably less open than other WTO members. Instead of an interaction term as in Cao and Flach (2015), we conduct a different exercise and code these countries as non-members.

As expected, the results in columns (2) and (4) in Table 11 show that the WTO coefficients increase for both kinds of products if we apply the different WTO definition (for comparison, we report the coefficients with the standard definition in columns 1 and 3). Also in this specification, the effect

T A B LE 10 Results using first differences

\begin{tabular}{|c|c|c|c|}
\hline Dependent variable: $\Delta \ln p_{k i j \tau}$ & (1) & (2) & (3) \\
\hline \multirow{2}{*}{$\begin{array}{l}\Delta \text { WTO Both WTO Both } \times \\
\text { DIFF good }\end{array}$} & & $0.0359^{*}$ & $0.0378 *$ \\
\hline & & $(0.0136)$ & $(0.0148)$ \\
\hline \multirow[t]{2}{*}{$\Delta$ WTO Both } & 0.0650 & 0.0276 & 0.0233 \\
\hline & $(0.0607)$ & $(0.0256)$ & $(0.0234)$ \\
\hline \multirow[t]{2}{*}{$\Delta \mathrm{PTA}$} & & & $0.0370^{*}$ \\
\hline & & & $(0.0151)$ \\
\hline Fixed Effects & $j k \tau \& i k \tau$ & $j k \tau \& i k \tau$ & $j k \tau \& i k \tau$ \\
\hline Control Variable & $\ln \left(\mathrm{GDP}_{i \tau} \times \mathrm{GDP}_{j \tau}\right)$ & $\ln \left(\mathrm{GDP}_{i \tau} \times \mathrm{GDP}_{j \tau}\right)$ & $\ln \left(\mathrm{GDP}_{i \tau} \times \mathrm{GDP}_{j \tau}\right)$ \\
\hline Observations & $24,120,258$ & $24,120,258$ & $24,120,258$ \\
\hline$R^{2}$ & 0.201 & 0.201 & 0.201 \\
\hline
\end{tabular}

Note: Robust standard errors are shown in parentheses.

Abbreviations: DIFF, differentiated; HOM, homogeneous.

***,**** Denotes significance at the $1 \%, 5 \%$, and $10 \%$ level, respectively. 
T A B LE 11 Robustness checks-Official versus unofficial members

\begin{tabular}{|c|c|c|c|c|}
\hline & \multicolumn{2}{|c|}{ Sample without tariff } & \multicolumn{2}{|c|}{ Sample with tariff } \\
\hline & (1) & (2) & (3) & (4) \\
\hline WTO $\times$ DIFF. Good & $\begin{array}{l}0.077 * * \\
(0.022)\end{array}$ & & $\begin{array}{l}0.074 * * \\
(0.025)\end{array}$ & \\
\hline WTO $\times$ HOM. Good & $\begin{array}{l}0.028 \\
(0.030)\end{array}$ & & $\begin{array}{l}0.021 \\
(0.036)\end{array}$ & \\
\hline PTA & $\begin{array}{l}0.041 \\
(0.031)\end{array}$ & $\begin{array}{l}0.041 \\
(0.031)\end{array}$ & $\begin{array}{l}0.072 * \\
(0.029)\end{array}$ & $\begin{array}{l}0.072 * \\
(0.029)\end{array}$ \\
\hline PTA Depth $\times$ DIFF. Good & $\begin{array}{l}-0.004 \\
(0.004)\end{array}$ & $\begin{array}{l}-0.004 \\
(0.004)\end{array}$ & $\begin{array}{l}-0.014 * \\
(0.006)\end{array}$ & $\begin{array}{l}-0.014 * \\
(0.006)\end{array}$ \\
\hline $\begin{array}{l}\text { PTA Depth × HOM. } \\
\text { Good }\end{array}$ & $\begin{array}{l}-0.007 \\
(0.006)\end{array}$ & $\begin{array}{l}-0.007 \\
(0.006)\end{array}$ & $\begin{array}{l}-0.009 \\
(0.007)\end{array}$ & $\begin{array}{l}-0.009 \\
(0.007)\end{array}$ \\
\hline $\begin{array}{l}\text { Diff. WTO Def. × DIFF. } \\
\text { Good }\end{array}$ & & $\begin{array}{l}0.093 * * \\
(0.021)\end{array}$ & & $\begin{array}{l}0.090 * * \\
(0.023)\end{array}$ \\
\hline $\begin{array}{l}\text { Diff. WTO Def. × HOM. } \\
\text { Good }\end{array}$ & & $\begin{array}{l}0.038 \\
(0.030)\end{array}$ & & $\begin{array}{l}0.027 \\
(0.038)\end{array}$ \\
\hline Observations & 33,051 & 33,051 & 24,315 & 24,315 \\
\hline RMSE & 0.959 & 0.959 & 0.946 & 0.946 \\
\hline Adjusted $R^{2}$ & 0.716 & 0.716 & 0.714 & 0.714 \\
\hline $\mathrm{FE}$ & $t \& i j k$ & $t \& i j k$ & $t \& i j k$ & $t \& i j k$ \\
\hline
\end{tabular}

Note: Robust standard errors are shown in parentheses.

Abbreviations: DIFF, differentiated; HOM, homogeneous. Number of observations in 1,000.

$* * *, * *, *$ Denotes significance at the $1 \%, 5 \%$, and $10 \%$ level, respectively. Robust standard errors two-way clustered by importer-exporter-product and time groups, see Cameron et al. (2011).

is only significant and higher in magnitudes for differentiated goods. The size and significance levels of real GDP coefficients and tariffs do not change and are not reported throughout the table.

\subsection{Heterogeneous effects of trade agreements}

We expect trade agreements to have heterogeneous effects on prices. In this section we document several patterns in the data that highlight the heterogeneous nature of trade agreements.

\subsubsection{Article XXVI5(c) and the heterogeneity among new WTO members}

Until the end of 1994, some countries (listed in Table A1) entered GATT under Article XXVI5(c) without strict commitments to policy reforms. In particular, former colonies could invoke Article XXVI5(c) upon becoming independent. ${ }^{27}$ While other countries conducted extensive reforms and passed through long negotiations processes, countries under Article XXVI5(c) became members by sending a request to GATT (a more detailed description of Article XXVI5(c) is provided by Tang and Wei (2009)).

In Table 12 (columns 1 and 2) we exploit the heterogeneity between the two groups of new WTO members. We show that the effect of membership on prices comes entirely from the developing 
TA B L E 12 Application versus accession and membership under Article XXVI5(c)

\begin{tabular}{|c|c|c|c|c|}
\hline $\begin{array}{l}\text { Dependent variable: } \ln p_{k i j \tau} \\
\text { (from Comtrade) }\end{array}$ & (1) & (2) & (3) & (4) \\
\hline$W T O_{i t}$ & $0.0761 * * *$ & & $\begin{array}{l}0.0399 * \\
(0.0206)\end{array}$ & \\
\hline$W T O_{j t}$ & $\begin{array}{l}0.00867 \\
(0.0174)\end{array}$ & & $\begin{array}{l}0.0334 * * * \\
(0.0103)\end{array}$ & \\
\hline$W T O_{i t} \times$ ArticleXXVI $_{i}$ & $\begin{array}{l}-0.0981 * * \\
(0.0449)\end{array}$ & & & \\
\hline$W T O_{j t} \times \operatorname{ArticleXXVI}_{j}$ & $\begin{array}{l}0.0210 \\
(0.0292)\end{array}$ & & & \\
\hline$W T O_{i j t}$ & & $\begin{array}{l}0.0267 * \\
(0.0142)\end{array}$ & & $\begin{array}{l}0.0249 * * \\
(0.0125)\end{array}$ \\
\hline$W T O_{i j t} \times \operatorname{ArticleXXVI}_{i j t}$ & & $\begin{array}{l}-0.00850 \\
(0.0242)\end{array}$ & & \\
\hline Application $_{i t}$ & & & $\begin{array}{l}-0.0571 * * * \\
(0.0122)\end{array}$ & \\
\hline Application $_{j t}$ & & & $\begin{array}{l}0.0215 \\
(0.0156)\end{array}$ & \\
\hline Application $_{i j t}$ & & & & $\begin{array}{l}0.000131 \\
(0.00755)\end{array}$ \\
\hline $\ln \left(\mathrm{GDP}_{i \tau} \times \mathrm{GDP}_{j \tau}\right)$ & $\begin{array}{l}0.101 * * * \\
(0.0115)\end{array}$ & $\begin{array}{l}0.101 * * * \\
(0.0115)\end{array}$ & $\begin{array}{l}0.0987 * * * \\
(0.0115)\end{array}$ & $\begin{array}{l}0.101 * * * \\
(0.0115)\end{array}$ \\
\hline Observations & $2,234,837$ & $2,234,837$ & $2,234,837$ & $2,234,837$ \\
\hline$R^{2}$ & 0.956 & 0.956 & 0.956 & 0.956 \\
\hline Fixed effects & $t \& i j s$ & $t \& i j s$ & $t \& i j s$ & $t \& i j s$ \\
\hline
\end{tabular}

Note: Robust standard errors are shown in parentheses.

Abbreviations: DIFF, differentiated; HOM, homogeneous.

The sample used in this table refers to Comtrade data at the SITC2 four-digit classification. Four-digit sectors are indexed by $s$. $* * *, * * *$ Denotes significance at the $1 \%, 5 \%$, and $10 \%$ level, respectively. Robust standard errors two-way clustered by importerexporter-product and time groups, see Cameron et al. (2011).

countries that committed to trade policy, which involved binding commitments and long negotiation efforts. This result is shown by the interaction between WTO with a dummy Art XXVI=1 if a country ( $i$ or $j$ ) was subject to Article XXVI5(c). For country $i$, we even find a negative effect for the interaction term on prices.

Note that, because the BACI data is not available for the years prior to 1995, for this exercise we use Comtrade data documented by Feenstra, Lipsey, Deng, Ma, and Mo (2005)at the SITC2 (Standard International Trade Classification) four-digit classification, indexed by $s$. The data contains information not only on trade values, but also on quantities and unit of measurement by country pair, year, and product. However, the drawback in comparison with the BACI data is that, in the Comtrade data documented by Feenstra et al. (2005), trade values are taken from importers and are, thus, import CIF (cost, insurance and freight) prices. Hence, one should be cautious when comparing the results in this section with the other results in the paper, where FOB prices are used. 
One important concern regarding the validity of these results is comparability between the two schemes. The inclusion of $i j$ fixed effects in the estimation is helpful but does not rule out biases coming from systematic differences between Article XXVI5(c) and non-Article XXVI5(c) countries. Moreover, since many of the countries under Article XXVI5(c) are small island economies, we do observe systematic differences in country characteristics in levels, when we compare them with nonArticle XXVI5(c) countries. However, one crucial argument in our favor is the fact that the pre-accession behavior of prices between the two groups is very similar, whereas the average post-accession of non-Article XXVI 5(c) countries is significantly different.

\subsection{2 | Comparability of residuals between new members and a control group}

A concern with our analysis could be that prior to membership in a trade agreement there are intrinsic differences in the paths of prices of new members in comparison with other countries. If countries are already conducting major policy changes, new members and further countries are no longer comparable. To assess this concern, we check the residuals of the regressions on prices for new members (4 years before WTO or PTA membership) and a control group (referring to non-members and old members). We compute the residuals for the treatment and control group separately for importers and exporters. For WTO, we find that the means of residuals for treatment and control groups are both near zero ${ }^{28}$ and the standard deviation is lower than 0.15 . Similar values are found for PTAs, although in this case the standard deviation is slightly higher. Hence, prior to accession, the price behavior appears to be similar to the behavior of our control group.

\subsection{3 | The long time gap between application and accession}

Another concern with our results could be the long time gap between application and accession. For instance, countries that apply for a trade agreement might already be conducting policies towards more economic stability, world market integration, etc. In this case, membership could capture an effect that would have happened anyway. Or, if these policies are due to WTO application, our coefficient on membership would only capture part of the effect. We assess this concern by exploiting available data on the time gap between application and accession to WTO, using the long and variable time lags between application and accession. The dummy variable stands for Application $=1$ for the periods between application and accession. Perhaps surprisingly, the coefficients for application are not significant, as shown in columns (3) and (4) in Table 12. However, if we divide countries according to the time of negotiation, we also see that this effect is mostly driven by countries that had longer periods of negotiations (longer than 5 years), whereas for the other countries the effect of Application on prices is significant at $10 \%$ for country $j .{ }^{29}$ Crucially, the WTO variables remain stable and significant.

\subsection{4 | Phased-in trade agreements and lagged effects}

We investigate the possibility that PTAs have delayed effects on prices. Baier and Bergstrand (2007) suggest that all FTAs are phased-in over time, typically over 5 to 10 years. ${ }^{30} \mathrm{~A}$ trade agreement that enters the sample in one year (date of entry into force) might only come into an economic effect years later. Hence, our variable for trade agreements might not capture the full effect and underestimate the effect on prices. ${ }^{31}$ In Table 13 (column 1), we check whether PTAs have a lagged effect on prices, using the first two lags of the variable. We find that the first lag of PTA $\left(\mathrm{PTA}_{i j, \tau-1}\right)$ is positive and even larger than $\mathrm{PTA}_{i j, \tau}$, which could indicate some cumulative effect on prices, whereas the second 
T A B L E 13 Phased-in trade agreements and lagged effects on prices

\begin{tabular}{|c|c|c|}
\hline Dependent variable: $\ln p_{k i j \tau}$ & (1) & (2) \\
\hline $\mathrm{PTA}_{i j, \tau}$ & $\begin{array}{l}0.0106^{*} \\
(0.00491)\end{array}$ & \\
\hline $\mathrm{PTA}_{i j, \tau-1}$ & $\begin{array}{l}0.0231 \\
(0.0123)\end{array}$ & \\
\hline $\mathrm{PTA}_{i j, \tau-2}$ & $\begin{array}{l}-0.000641 \\
(0.00679)\end{array}$ & \\
\hline $\mathrm{WTO}_{i j, \tau}$ & & $\begin{array}{l}0.0697^{*} \\
(0.0259)\end{array}$ \\
\hline $\mathrm{WTO}_{i j, \tau-1}$ & & $\begin{array}{l}0.00995 \\
(0.00939)\end{array}$ \\
\hline $\mathrm{WTO}_{i j, \tau-2}$ & & $\begin{array}{l}-0.0180 \\
(0.0101)\end{array}$ \\
\hline Observations & $33,161,901$ & $33,161,901$ \\
\hline$R^{2}$ & 0.793 & 0.793 \\
\hline Fixed effects & $t \& i j k$ & $t \& i j k$ \\
\hline Control variable & $\ln \left(\mathrm{GDP}_{i \tau} \times \mathrm{GDP}_{j \tau}\right)$ & $\begin{array}{c}\ln \left(\mathrm{GDP}_{i \tau} \times\right. \\
\left.\mathrm{GDP}_{j \tau}\right)\end{array}$ \\
\hline
\end{tabular}

Notes: Robust standard errors are shown in parentheses.

Abbreviations: DIFF, differentiated; HOM, homogeneous.

Results include $\ln \left(\mathrm{GDP}_{i t} \times \mathrm{GDP}_{j t}\right)$ as control variable.

***,**,* Denotes significance at the $1 \%, 5 \%$, and $10 \%$ level, respectively. Robust standard errors two-way clustered by importer-exporter-product and time groups, see Cameron et al. (2011).

lag is negative. However, none of them are statistically significant. Even though the phase-in period is of 5 to 10 years, it is important to recall that our data is already averaged over 4 years. Hence, the first lag of 4 years might capture part of the effect. A similar analysis can be conducted for the WTO variable. We have already shown the long time gap between application and accession. Instead, in this robustness check we can evaluate a lagged effect of WTO on prices. In Table 13 (column 2), we show that the lagged effect for WTO is very small and not significant. Hence, we cannot confirm the presence of the lagged effect on prices.

\subsection{5 | Interaction term between WTO membership and the year of entry}

We also exploit the timing of WTO membership within every period. Because we use 4-year averages in the estimations, it could be that a country that joins WTO in the first year of the period experiences a distinct effect on prices in comparison with a country that joins in the last year of the period. We investigate this hypothesis in the data, using interaction terms between WTO and the year of change in membership status. We generate an interaction term between WTO and membership in the first year of every period (WTO $\times 1$ st year), and another interaction term between WTO and membership in the fourth year of the period (WTO $\times 4$ th year). As shown in Table A8 in the Appendix, perhaps surprisingly, the coefficients for WTO remain similar. The coefficient for the interaction term WTO $\times 1$ st year is positive whereas for WTO $\times 4$ th year it is negative, which could suggest that it takes time to observe an effect on prices. However, none of the interaction terms are significant. 


\section{6 | CONCLUSION}

Despite the large interest and discussion concerning the trade promoting effects of membership in multilateral trade agreements, little is known about the effect of membership on world trade prices. Multilateral trade agreements lower trade barriers on imported goods, which might affect export prices not only through a cost effect but also through access to better quality products and the innovation behavior of firms. Besides tariffs, other channels such as changes in the regulations and investment rules between members have been discussed by the literature. Hence, the net effect on export prices is a priori unclear.

Using the most comprehensive data available on FOB export prices for world trade flows at the product level, we show that membership in trade agreements is associated with an increase in export prices of differentiated goods. For WTO, we show that this effect is captured by the countries that were subject to rigorous WTO accession procedures and not to accession under Article XXVI 5(c). Moreover, for intermediate goods, we show that membership is only significant when the importer joins WTO. Besides the analysis of trade agreements as a binary choice, we exploit the importance of the depth of an PTA and of its different provisions. Although the depth measure is not significant in the full sample, we show that individual provisions such as investments are associated with higher trade prices.

We offer a first attempt to measure the effect of trade agreements on export prices for all countries and all manufacturing products. Although the aggregate data at the product level hides important composition effects, the positive relation we find is consistent with the literature that relates trade liberalization to innovation, endogenous markups, and quality upgrading.

Our paper does not draw direct policy implications. However, it suggests that, if we disregard the impact of trade agreements on innovation and quality upgrading, we might wrongly evaluate their price and welfare effects. Moreover, as discussed by Amiti and Khandelwal (2013), the production of high-quality goods is often viewed as a pre-condition for economic development. Hence, it is important to understand whether trade agreements foster competition and influence the transition towards production of higher-quality products.

\section{ACKNOWLEDGMENT}

The authors thank the German Science Foundation for financial support through Grant No. CRC TRR 190. All data sources used in our paper are publicly available for researchers and we provide information regarding the sources in the paper. Researchers willing to replicate our results are welcome to contact the authors for more information.

\section{DATA AVAILABILITY STATEMENT}

This is a data availability statement for the manuscript The impact of trade agreements on world export prices. All data sources used in our paper are publicly available for researchers and we provide information regarding the sources in the paper. Researchers willing to replicate our results are welcome to contact the authors for more information.

\section{ORCID}

Lisandra Flach (iD http://orcid.org/0000-0003-2000-6445 


\section{ENDNOTES}

${ }^{1}$ Rose's seminal 2004 papers neither found evidence that membership at GATT/WTO (General Agreement on Tariffs and Trade/World Trade Organiization) has increased trade (Rose, 2004a) nor that it has led to a more open trade policy of its members (Rose, 2004b). These papers motivated a large literature on the trade-promoting effects of trade agreements.

${ }^{2}$ In their 2002 paper, Chang and Winters (2002) study the effect of regional integration on trade prices and note with surprise that "there is not a single ex post empirical study of the price effects of integration" apart from their own 2000 paper. One possible explanation is the lack of free on board price data. In recent years, few studies have investigated the price effects of trade liberalization (for instance, Amiti \& Khandelwal, 2013; Fan et al., 2015). However, these studies focus on the experience of one country, whereas we are interested in general equilibrium effects using all events of PTAs and WTO membership in recent years.

${ }^{3}$ According to the recently released Desta dataset that we use in this paper, one can divide the provisions of an PTA in seven groups, where tariffs represent only one of the seven provisions. Moreover, for the WTO, Ossa (2016) writes, for instance, that WTO rules also limit foreign direct investment (FDI) policies that governments can apply. For example, the Trade Related Investment Measures (TRIMS) agreement limits the local content requirements that can be imposed on foreignowned firms. Also, FDI flows are increasingly subject to bilateral investment treaties (Ossa, 2016).

${ }^{4} \mathrm{As}$ we describe in more detail in the data section, average prices from BACI are more reliable in comparison with Comtrade. Moreover, at BACI transportation costs are always removed, such that the results can be consistently interpreted in terms of FOB export prices (see Gaulier \& Zignano, 2010).

${ }^{5}$ Until the end of 1994, some countries (listed in Table A1) entered GATT/WTO under Article XXVI5(c). While other countries conducted extensive reforms and passed through long negotiations processes, in particular many former colonies turned WTO members by invoking Article XXVI5(c) (a more detailed description of Article XXVI5(c) is provided by Tang and Wei (2009)). These countries were not obliged to conduct structural reforms and are arguably less open than other WTO members.

${ }^{6}$ For firms selling high-quality products, it reduces the cannibalization of existing profits and enables incumbent firms to escape from the threat of competition. Aghion et al. (2009) refer to this as the escape-entry effect (see also Aghion, Bloom, Blundell, Gric, \& Howitt, 2005).

${ }^{7}$ As discussed in Goldberg et al. (2016), most studies focus on the pro-competitive effects from a decline in output tariffs, but a trade reform also lowers tariffs on imported inputs. These two tariff reductions represent distinct shocks to domestic firms. On the one hand, a decrease in output tariffs decreases producer surplus of domestic firms. On the other hand, because input tariffs decrease, firms benefit from lower production costs. The price decline depends on the extent to which firms pass cost savings of a decrease in input tariffs to consumers, and might be small as firms could react by raising markups (see Goldberg et al., 2016).

${ }^{8}$ Moreover, several papers show empirical evidence that import competition leads to quality investments (Martin \& Mjean, 2014; Bloom, Draca \& Rennen, 2016; Utar, 2014). Martin and Mjean (2014) show that import competition leads to quality upgrading for French firms. Bloom et al. (2016) and Utar (2014) find evidence that competitive pressures from Chinese products, in particular following WTO membership, make firms rely more on innovation.

${ }^{9}$ For homogeneous goods we do not expect either a quality effect or a cost effect, leaving prices by and large unaffected. First, homogeneous goods are not affected by access to cheaper/better imported inputs, in contrast to most differentiated goods. Second, homogeneous goods are less likely to observe quality upgrading. Third, as we use FOB prices, changes in freight and insurance costs following trade liberalization do not directly affect prices.

${ }^{10}$ Whereas Fan et al. (2015) exploit in detail the experience of one country following membership in the WTO, our results are more general. Moreover, a reduction in tariffs as investigated by Fan et al. (2015) was certainly a condition for China to join the WTO; however, other requirements might as well affect export prices after WTO accession, as discussed in the literature (see Baier \& Bergstrand, 2007). In fact, our results remain significant even when controlling for tariffs, which suggests that other mechanisms are important to explain the effect of trade agreements.

${ }^{11}$ The incomplete pass-through is not present in CES (constant elasticity of substitution) models, which are widely used in the trade literature. One exception of a paper that discusses quality and variable markups is Hottman, Redding, and Weinstein (2016). They show that most firms are well approximated by monopolistic competition models with constant markups, but that in particular the largest firms exhibit variable markups. 
${ }^{12}$ In the Data Appendix, we briefly sketch how Gaulier and Zignano (2010) construct the BACI data.

${ }^{13}$ The user-written commands for STATA (shp2dta, spmap) stem from Kevin Crow and Maurizio Pisati. Data can be downloaded, e.g., from the Natural Earth website.

${ }^{14}$ Period 1 shows the depth measure over 4,710 agreements, whereas period 5 shows the depth over 7,061 agreements. While depth increased, the number of agreements between many country pairs also increased. Hence, for some countries it happens that on average for a specific country pair, trade agreements become rather shallow, as shown in Figure A1.

${ }^{15}$ Note that, by coding the WTO variable as described above, we obtain a variable that varies in the exporter-importer-time dimension. However, different from the PTA, this variable is only cardinally interpretable since we look at the effect of an increase from zero to one and one to two. Hence, we also estimate the baseline results with separated importer-time $\left(\mathrm{WTO}_{j \tau}\right)$ and exporter-time $\left(\mathrm{WTO}_{i \tau}\right)$ variables along with an interaction term WTO-Both $\mathrm{W}_{i \tau}$.

${ }^{16}$ The intuition is that the cheapest products, with lower marginal costs, are the most competitive in a model with CES preferences that allows for firm heterogeneity, see Melitz (2003).

${ }^{17}$ To simplify the analysis, we control for the product of the countries' GDPs.

${ }^{18}$ Because of the large amount of product-exporter-importer categories, we use the user-written command "reghdfe" written by Correia (2014) who further develops the work of Guimaraes and Portugal (2010). This procedure allows for fixed effects in multiple dimensions and for multi-way clustering.

${ }^{19}$ In both cases the two-way clustering including time clusters implies a higher $p$ value.

${ }^{20}$ See Aghion et al. (2005, 2009). Note that, as in Amiti and Khandelwal (2013), our results are at the product level.

${ }^{21}$ See also Goldberg and Pavcnik (2016) on the incomplete pass-through following trade agreements.

${ }^{22}$ The fact that the results are not significant for PTAs might again indicate the importance of closer evaluation of the different provisions within a trade agreement.

${ }^{23}$ This is made computationally possible thanks to the stata command written by Correia (2014).

${ }^{24}$ The reason for the choice of the reference importer and exporter is the size and diversity of the U.S. and the German economies, which allow us to observe and reference as many traded products as possible.

${ }^{25}$ This implies that the results are not directly comparable $i$ th the results using Germany as baseline. To compare the results, we have to assume that the price of Chinese export products to any other country, price $_{C H N, j}$, changes at the same rate as the price of Chinese export products to the United States, price ${ }_{C H N, U S \tau}$, and therefore the endogeneity problem caused by Chinese WTO accession is removed in the ratio.

${ }^{26}$ See data section in the Section A1 of the Appendix for further information.

${ }^{27}$ As discussed by Tang and Wei (2009), Cambodia and Algeria, former French colonies, were the only two countries eligible for Article XXVI5(c) that did not make use of this article. Both of them made important efforts to accede to GATT/WTO on their own, instead of asking France to sponsor their accession. The latter was a requirement for invoking membership in the terms of Article XXVI5(c).

${ }^{28}$ The means for importers are 0.15 and 0.09 for treatment and control group, respectively. The means for exporters are 0.12 and 0.08 for treatment and control group, respectively.

${ }^{29}$ These results can be reconciled with Tang and Wei (2009), who use application dates to investigate the effect of membership on growth rates. They show that application to WTO increased growth rates temporarily, but actual accession had a stronger effect on growth.

${ }^{30}$ Baier and Bergstrand (2007) provide the example of NAFTA or the original EEC agreement, which had a 10-year phase-in period.

${ }^{31}$ For trade flows, Besedes, Kohl, and Lake (2018) provide empirical evidence on the relevance of the phase-out of tariffs as an explanation for the delayed impact of trade agreements.

${ }^{32}$ These numbers are based on the data. The inconsistency with information from the WTO website for founding members - they count 23 founding members — stems from the fact that we do not consider countries that dissolved and/or exited the GATT.

${ }^{33}$ In doing so, we follow Martin, Mayer, and Thoenig (2008) who code their GATT variable by counting the members within a country pair. 
${ }^{34}$ De facto members, provisional members, members that joined the GATT under Article XXXIII, and original members do not change their status in the observed time, and, hence, do not influence our analysis; colonies and Article XXVI:5(c) accessions are only considered in the Robustness Checks section (Section 5).

${ }^{35}$ We abstain from including the product subscript since it does not increase understanding.

${ }^{36}$ When a country cuts tariffs and has market power on the world market, this effects the country's export prices—and the terms of trade.

${ }^{37}$ The motivation for the correction factor $\lambda$ is to control for the long-run world-wide average trade deficit when calculating $C A_{i k t}$.

${ }^{38}$ See unstats.un.org/unsd/trade/classifications/correspondence-tables.asp.

\section{REFERENCES}

Aghion, P., Bloom, N., Blundell, R., Gric, R., \& Howitt, P. (2005). Competition and innovation: An inverted U relationship. Quarterly Journal of Economics, 120(2), 701-728.

Aghion, P., Blundell, R., Gric, R., Howitt, P., \& Prantl, S. (2009). The effects of entry on incumbent innovation and productivity. Review of Economics and Statistics, 91(1), 20-32.

Amiti, M., \& Khandelwal, A. (2013). Import competition and quality upgrading. Review of Economics and Statistics, 95(2), 476-490.

Anderson, J. E., \& Van Wincoop, E. (2003). Gravity with gravitas: A solution to the border puzzle. American Economic Review, 93(1), 170-192.

Baier, S., \& Bergstrand, J. (2007). Do free trade agreements actually increase members' international trade? Journal of International Economics, 71, 72-95.

Bertrand, M., Duflo, E., \& Mullainathan, S. (2004). How much should we trust differences in differences estimates? The Quarterly Journal of Economics, 119(1), 249-275.

Besedes, T., Kohl, T., \& Lake, J. (2018). Phase out tariffs, phase in trade? Dallas, TX: Southern Methodist University.

Bloom, N., Draca, M., \& Rennen, J. V. (2016). Trade induced technical change? The impact of Chinese imports on innovation, it and productivity. Review of Economic Studies, 83(1), 87-117.

Breinlich, H., Dhingra, S., \& Berlingier, G. (2018). The impact of trade agreements on consumer welfare. Journal of the European Economic Association, 16(6), 1881-1928.

Bustos, P. (2011). Trade liberalization, exports, and technology upgrading: Evidence on the impact of Mercosur on Argentinian firms. American Economic Review, 11, 304340.

Cameron, A. C., Gelbach, J. B., \& Miller, D. L. (2011). Robust inference with multiway clustering. Journal of Business and Economic Statistics, 29(2), 238-249.

Cao, V., \& Flach, L. (2015). The effect of GATT/WTO on export and import price volatility. The World Economy, 38, 2049-2079.

Chang, W., \& Winters, A. (2002). How regional blocs affect exluded countries: The price effects of Mercosur. American Economic Review, 92(4), 889-904.

Chisik, R. (2012). Trade disputes, quality choice, and economic integration. Journal of International Economics, 88, $47-61$.

Correia, S. (2014). reghdfe: Stata module to perform linear or intrumentalvariable regression absorbing any number of high-dimensional fixed effects (Working Paper). http://scorreia.com/software/reghdfe/index.html

Dür, A., Baccini, L., \& Elsig, M., (2014). The design of international trade agreements: Introducing a new dataset. The Review of. International Organization, 9(3), 353-375.

Fan, H., Li, Y., \& Yeaple, S. R. (2015). Trade liberalization, quality, and export prices. Review of Economics and Statistics, 97(5), 1033-1051.

Feenstra, R. C., Inklaar, R., \& Timmer, M. (2015). The next generation of Penn World Table. American Economic Review, 105(10), 3150-3182.

Feenstra, R. C., Lipsey, R. E., Deng, H., Ma, A. C., \& Mo, H. (2005). World trade flows: 1962-2000 (NBER Working paper No. 11040). Cambridge, MA: National Bureau of Economic Research.

Gaulier, G., \& Zignano, S. (2010). BACI: International trade database at the product-level the 1994-2007 version (CEPII Working Paper 2010-23). Paris, France: Centre d'Etudes Prospectives et d'Informations Internationales.

Goldberg, P., Khandelwal, A., Pavcnik, N., \& De Loecker, J. (2016). Prices, markups and trade reform. American Economic R, 84(2), 445-510. 
Goldberg, P., \& Pavcnik, N. (2016). The effects of trade policy. Handbook of Commercial Policy, 1, 161-206.

Guimaraes, P., \& Portugal, P. (2010). A simple feasible alternative procedure to estimate models with high-dimensional fixed effects. Stata Journal, 10(4), 628-649.

Hallak, J. C. (2006). Product quality and the direction of trade. Journal of International Economics, 68(1), $238-265$.

Head, K., Mayer, T., \& Ries, J. (2010). The erosion of colonial trade linkages after independence. Journal of International Economics, 81(1), 1-14.

Hottman, C., Redding, S. J., \& Weinstein, D. E. (2016). Quantifying the sources of firm heterogeneity. Quarterly Journal of Economics, 131(3), 1291-1364.

Kugler, M., \& Verhoogen, E. (2012). Prices, plant size, and product quality. Review of Economic Studies, 79(1), 307-339.

Lake, J., \& Linask, M. (2016). Could tariffs be pro-cyclical? Journal of International Economics, 103, $124-146$.

Martin, J., \& Mjean, I. (2014). Low-wage country competition and the quality content of high-wage country exports. Journal of International Economics, 93(1), 140-152.

Martin, P., Mayer, T., \& Thoenig, M. (2008). Make trade not war? Review of Economic Studies, 75(3), 865-900.

Mayda, A. M., \& Rodrik, D. (2005). Why are some people (and countries) more protectionist than others. European Economic Review, 49(6), 1393-1430.

Melitz, M. J. (2003). The impact of trade on intra-industry reallocations and aggregate industry productivity. Econometrica, Econometric Society, 71(6), 1695-1725.

Ossa, R. (2016). Quantatitative models of commercial policy. In K. Bagwell \& R. W. Staiger (Eds.), Handbook of commercial policy (Vol. 1, Part A, pp. 207-260). Amsterdam, The Netherlands: Elsevier.

Pavcnik, N. (2002). Trade liberalization, exit, and productivity improvements: Evidence from chilean plants. The Review of Economic Studies, 69, 245-76.

Rauch, J. E. (1999). Networks versus markets in international trade. Journal of International Economics, 48(1), 7-35.

Rose, A. K. (2004a). Do we know that the WTO increase trades? American Economics Review, 94(1), 98-114.

Rose, A. K. (2004b). Do WTO members have more liberal trade policy? Journal of International Economics, 63(2), 209-235.

Subramanian, A., \& Wei, S.-J. (2007). The WTO promotes trade, strongly but unevenly. Journal of International Economics, 72(1), 151-175.

Tang, M.-K., \& Wei, S.-J. (2009). The value of making commitments externally: Evidence from WTO accessions. Journal of International Economics, 78(2), 216-229.

Tomz, M., Goldstein, J. L., \& Rivers, D. (2007). Do we really know that the WTO increases trade? comment. The American Economic Review, 97(5), 2005-2018.

Utar, H. (2014). When the floodgates open: Northern firms' response to removal of trade quotas on Chinese goods. American Economic Journal: Applied Economics, 6(4), 226-250.

World Bank (2016). WITS_Tariff and trade analysis. Washington, DC: The World Bank. Retrieved from https://wits. worldbank.org/WITS/WITS/Restricted/Login.aspx

WTO (2016). World Trade Organization-Members and observers. Geneva, Switzerland: World Trade Organization.

How to cite this article: Flach L, Gräf F. The impact of trade agreements on world export prices. Rev Int Econ. 2020;28:168-208. https://doi.org/10.1111/roie.12446

\section{APPENDIX A}

\section{A1. Data construction and summary statistics}

\section{A1.1 BACI}

In a first step Gaulier and Zignano (2010) make imports reported at CIF values comparable to exports reported at FOB values. They estimate transport costs using a gravity framework and remove the 
transport costs from the importer's reports. Applying this procedure they can recover missing exporter reports by using the same tradeflow reported by the importer instead. However, inconsistent mirror tradeflows are declared, even though exporters and importers should report the same value for the same tradeflow. Therefore, besides estimating transportation costs, Gaulier and Zignano (2010) assess the accuracy of each country's report and use these assessments to arrive at an averaged tradeflow value. Finally, if feasible, they convert all units into tons.

\section{A1.2 Prices}

Trade values are divided by quantities from the BACI to get unit values as a proxy for trade prices.

\section{A1.3 GATT/WTO}

Data on WTO membership until 2001 come from Tomz et al. (2007). A notable feature of the data is the distinction between formal members and participants that are not members. Apart from the GATT founding members (18 countries), formal members either became GATT members by undergoing the accession procedure according to Article XXXIII (45 countries), joined the GATT according to Article XXVI:5(c) (64 countries) or joined the WTO (32 countries), the successor of the GATT. ${ }^{32}$ Newly independent territories could negotiate accession according to Article XXXIII. In contrast, Article XXVI:5(c) allowed territories that gained independence to become GATT members under conditions negotiated by their former colonizers and thus without the need to implement reforms (Cao \& Flach, 2015). Tomz et al. (2007) also distinguish three types of non-member participants: colonies, de facto members, and provisional members. Countries in this group are not formal members of the GATT, but are entitled to the majority of rights that official GATT members have. De facto members are recently independent territories whose relation to the GATT has not been clarified after they gained independence and thus continue to be treated under GATT terms. Provisional non-members are defined as those countries that were granted GATT conditions while negotiations were still ongoing. However, no country has such a status in the period under observation in the data. Tomz et al. (2007) point out that de facto members were admitted for an unlimited time until the creation of the WTO. Note that, because we do not know if all de facto countries lost this status right away with the creation of the WTO, we keep the de facto status. De facto members are coded as nonmembers. Hence, in the data a country only loses its de facto status if it formally joins the WTO. Crucially, none of the results are affected by this procedure.

For the years following 2001, we take data from the official WTO website. For colonies, de facto participants, and countries that joined the WTO after 1995, we introduce a variable counting the number of countries within a country pair (maximum two, minimum zero) that became a member, or were a member, over the course of the observed time. ${ }^{33}$ For original member countries, accessions under Article XXVI:5(c), and accessions under Article XXXIII, the WTO measure reflects their status before the time period of interest. ${ }^{34}$

The Democratic Republic of Congo joined the WTO in 1997. We coded it as a direct WTO accession whereas Tomz et al. (2007) coded it as an accession under Article XXXIII. Hence, the country is recorded as entering the WTO in two different ways in the data. This is the reason the accessions mentioned in the text add up to 159 in time period 5 and the accessions (in Table 1) to 158 in time period 5. Moreover, adding up the GATT variables in Table 1 plus the new WTO accessions (see Table 2) should equal the number of WTO members in each time period. Owing to the coding status the number of WTO members is lower by one in each time period. However, this does not change the regression results in any way. 


\section{A1.4 PTAs}

The Desta database includes a main data file that lists the country pairs in a PTA and the year the PTA was finalized, a file with accession countries and the year they joined a certain PTA, and a file with add-on agreements, that is, when PTAs were renegotiated. First, we completed the main data file by adding the accession countries and the country pairs composed by accession countries only, for example, if Finland, Austria, and Sweden joined we added Finland-Sweden, Finland-Austria, AustriaSweden. We added these combinations for large treaties where several countries joined. Second, we generate a time variable and expand the dataset such that it varies over time and country pairs. Finally, we correct manually for sample attrition and add-on agreements and merge this data with a datafile containing the depth measure and one containing the seven different provisions. The depth measure and the average number of member countries was constructed as follows: if the same country pair was a member in multiple agreements, we include the agreement with the greatest depth value and calculate the average number of member states in all shared PTAs.

\section{A1.5 Tariffs}

The data come from WITS (World Bank, 2016). However, it contains several duplicate values with respect to the exporter, importer, time, and product category as this data also varied over different trade sources. To make the observations comparable, we keep the observations with Comtrade as a source. We use effectively applied tariffs and filled in missing tariff values. For instance, if Germany has tariff data for a certain product in the years 1996 and 1997 and then again in 2000, we use the 1997 tariff value for the years 1998 and 1999 (note that, for our estimations, we take 4 years average of the data). Another complication is that countries within the EU use the common EU tariff. We made the simplifying assumption that every EU member shares the same tariff rate on the same products at the same time as the EU. For some EU accessions after 2004 there were still country specific tariffs even 2 years after the accession date. In these (very few) cases, we keep the country specific tariffs to avoid duplicate values.

TAB LE A 1 Article XXVI5(c) members (accession between 1984 and 1999)

\begin{tabular}{|llll|}
\hline Country & Accession year & Country & Accession year \\
\hline Angola & 1994 & Liechtenstein & 1994 \\
\hline Antigua and Barbuda & 1987 & Macao, China & 1991 \\
\hline Bahrain & 1993 & Mali & 1993 \\
\hline Botswana & 1987 & Mozambique & 1992 \\
\hline Brunei Darussalam & 1993 & Namibia & 1992 \\
\hline Djibouti & 1994 & Papua New Guinea & 1994 \\
\hline Dominica & 1993 & Qatar & 1994 \\
\hline Fiji & 1993 & Saint Kitts and Nevis & 1994 \\
\hline Grenada & 1994 & Saint Lucia & 1993 \\
\hline Guinea & 1994 & Saint Vincent \& the Grenadines & 1993 \\
\hline Guinea Bissau & 1994 & Solomon Islands & 1994 \\
\hline Hong Kong, China & 1986 & Swaziland & 1993 \\
\hline Lesotho & 1988 & United Arab Emirates & 1994 \\
\hline
\end{tabular}

Source: WTO list of contracting parties, http://www.wto.org/english/res_e/booksp_e/gatt_ai_e/appendix_e.pdf. 


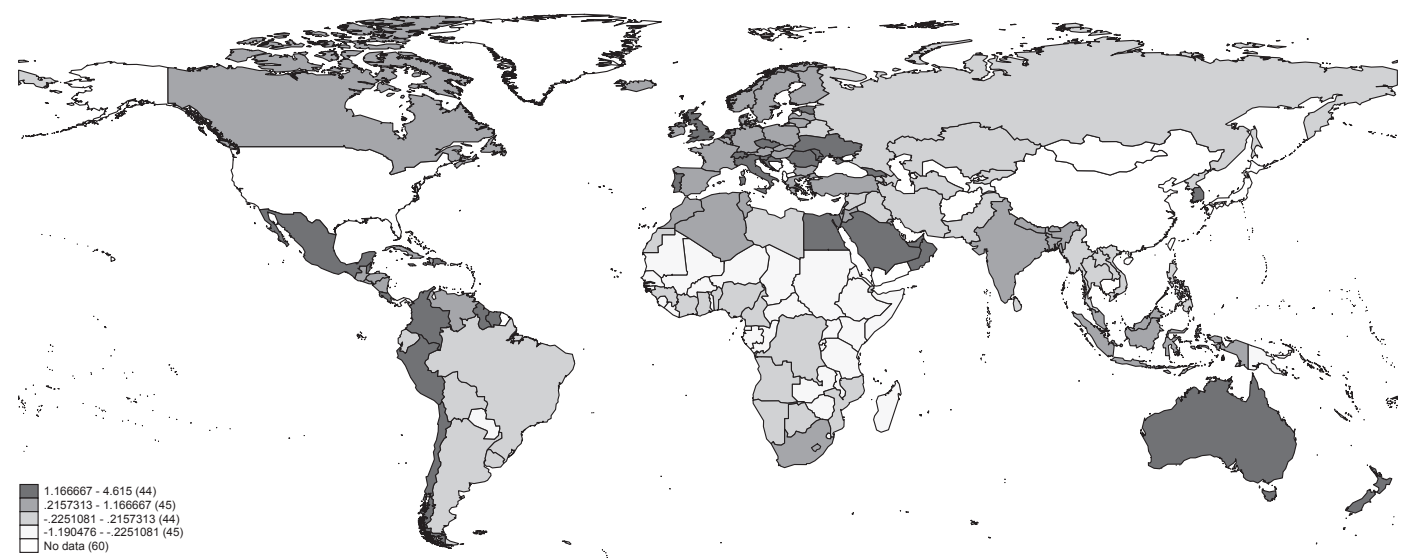

F I G URE A 1 Depth of PTAs, difference between period 1995-1998 and 2011-2014

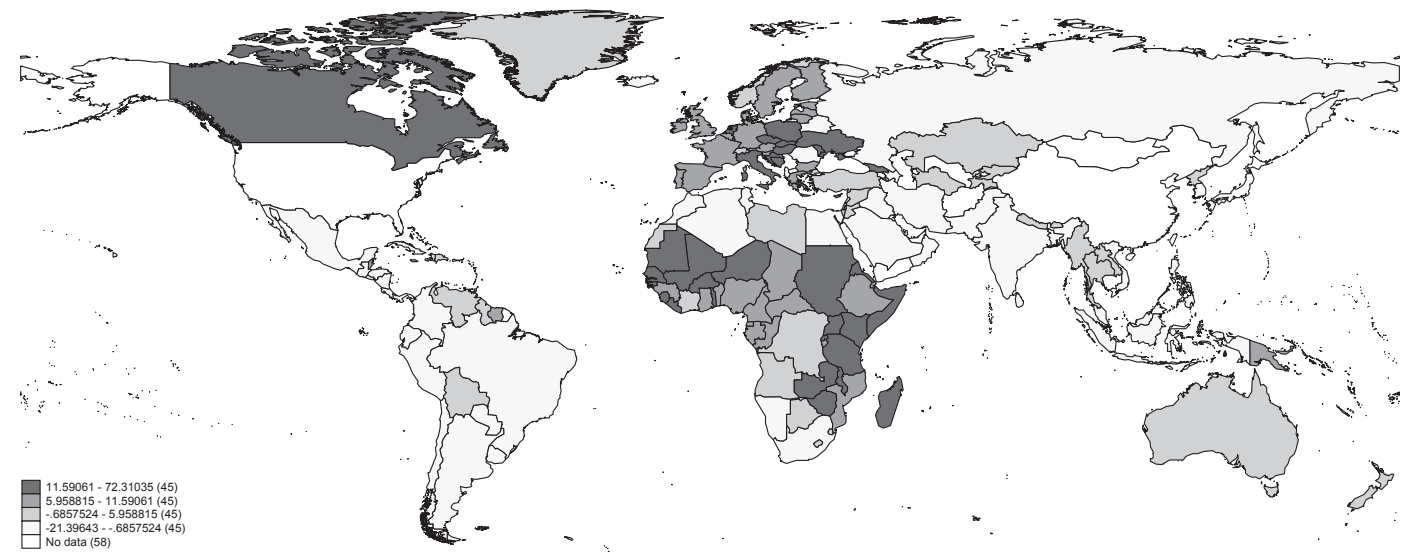

F IG URE A 2 Number of partner countries in PTAs, difference between period 1995-1998 and 2011-2014

\section{A2. Estimation methodology using tetrads}

The baseline results revealed that a WTO accession has distinct effects depending on the differentiation of the products and that the WTO and PTA variables are conditionally independent. We can corroborate both findings using the tetrad method. Anderson and Van Wincoop (2003) introduced the concept of multilateral resistance in the gravity estimation context and pointed out that not controlling for the importer and/or exporter specific unobserved multilateral resistance terms will lead to biased estimates. Many researchers (e.g., Hallak, 2006; Head et al., 2010) have used tetrads or some kind of ratio estimation to remove these multilateral resistance terms.

In our framework, the tetrad method proves helpful to control for unobserved heterogeneity in the exporter-time and importer-time dimension. Following Head et al. (2010), to conduct an estimation with tetrads, one essentially uses a reference importer and exporter, transforms all variables, and estimates the equation of interest with the transformed variables. We use the tetrad method as presented in Head et al. (2010) and choose the United States as the reference importer and Germany as the reference exporter.

$$
X_{\text {newVariable }}=\frac{X_{i, j} / X_{i, U S}}{X_{G E R, j} / X_{G E R, U S}} .
$$




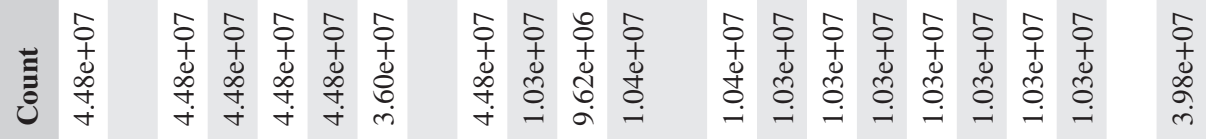

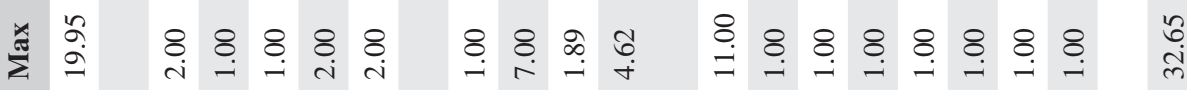

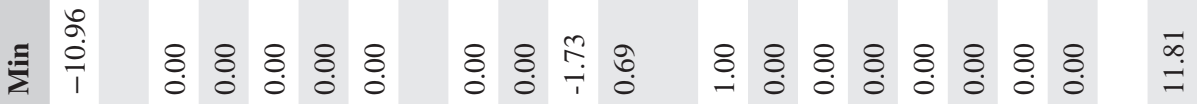

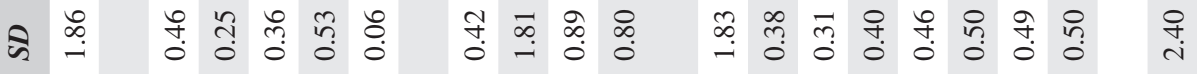

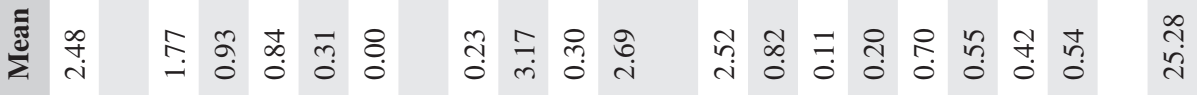

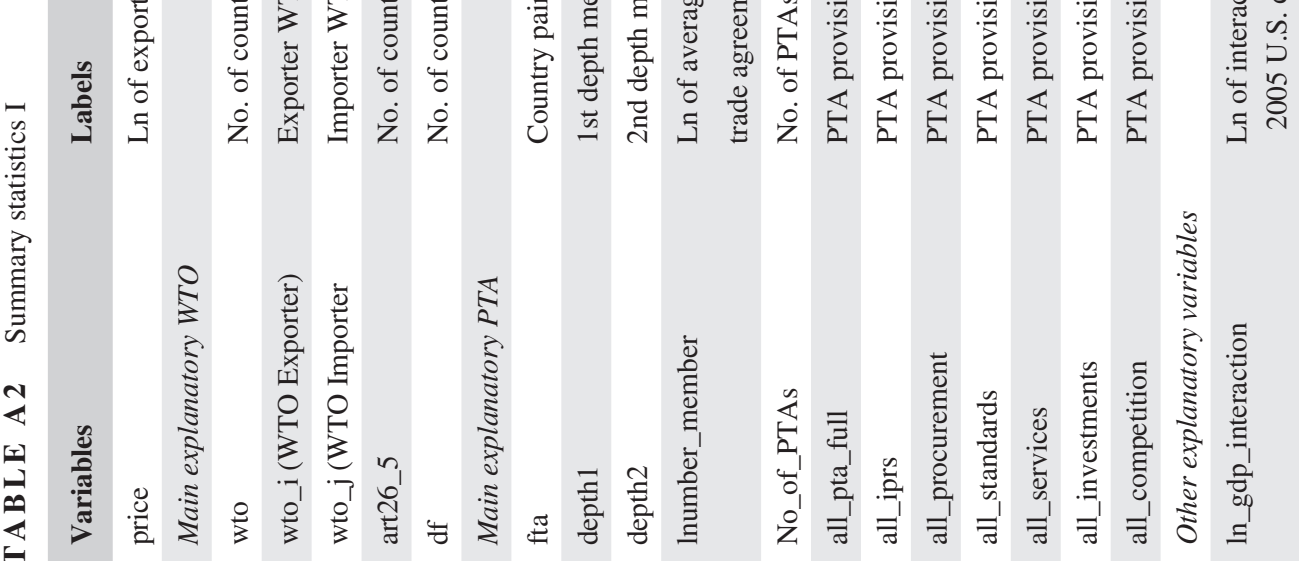




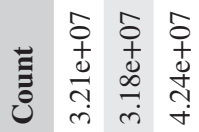

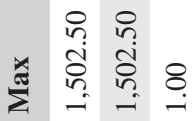

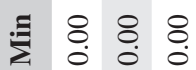

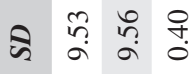

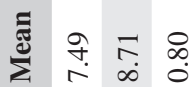

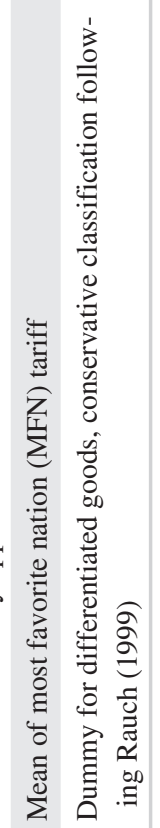

尽

๑ पे

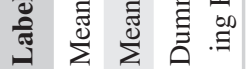

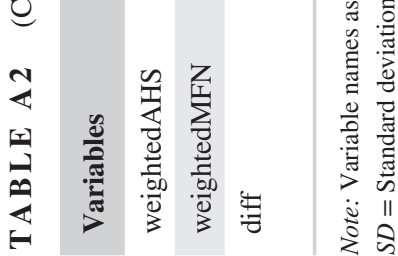


TA B LE A 3 Possible outcomes of transformed WTO variable

\begin{tabular}{|c|c|c|}
\hline & $i=1$ & $i=\mathbf{0}$ \\
\hline$j=1$ & $\frac{\frac{e_{i j}^{2}}{e_{i, U S}^{2}}}{\frac{e_{G E R, j}^{2}}{e_{G E R, U S}^{2}}}$ & 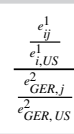 \\
\hline$j=0$ & $\frac{\frac{e_{i j}^{1}}{e_{i, U S}^{2}}}{\frac{e_{G E R, j}^{1}}{e_{G E R, U S}^{c}}}$ & $\frac{\frac{e_{i j}^{0}}{e_{i, U S}^{i}}}{\frac{e_{G E R, j}^{1}}{e_{G E R, U S}^{2}}}$ \\
\hline
\end{tabular}

Note: $i$ represents the exporter and $j$ the importer.

The reason for the choice of the reference importer and exporter is the size and diversity of the U.S. and the German eonomies, which allow us to observe and reference as many traded products as possible.

Reversing the logarithmic transformation the basic estimation equation with exporter-time and importer-time unobserved heterogeneity reads as follows:

$$
\text { price }_{k i j \tau}=g d p_{i \tau} g d p_{j \tau} \exp \left(W T O_{i \tau}+W T O_{j \tau}\right) \exp \left(\phi_{i \tau}\right) \exp \left(\delta_{j \tau}\right)
$$

where $\phi_{i \tau}$ represents exporter-time and $\delta_{j \tau}$ importer-time unobserved heterogeneity. Next, we show that a transformation as in Equation A1 removes the unobserved heterogeneity:

$$
\begin{aligned}
& \frac{\text { price }_{i j \tau} \text { price }_{i U S \tau}}{\text { price }_{G E R j \tau} \text { price }_{G E R, U S \tau}}=\frac{g d p_{i \tau} g d p_{j \tau} g d p_{i \tau} g d p_{U S \tau}}{g d p_{G E R \tau} g d p_{j \tau} g d p_{G E R \tau} g d p_{U S \tau}} \\
& \frac{\exp \left(W T O_{i \tau}+W T O_{j \tau}\right) \exp \left(W T O_{i \tau}+W T O_{U S \tau}\right)}{\exp \left(W T O_{G E R \tau}+W T O_{j \tau}\right) \exp \left(W T O_{G E R \tau}+W T O_{U S \tau}\right)} \frac{\exp \left(\phi_{i} \tau\right) \exp \left(\phi_{i} \tau\right)}{\exp \left(\phi_{G E R \tau}\right) \exp \left(\phi_{G E R \tau}\right)} \frac{\exp \left(\delta_{j} \tau\right) \exp \left(\delta_{U S \tau}\right)}{\exp \left(\delta_{j} \tau\right) \exp \left(\delta_{U S \tau}\right)}
\end{aligned}
$$

where the last two elements cancel out. ${ }^{35}$ Taking the natural logarithm in Equation A3 we arrive at an estimable specification free of importer-time and exporter-time unobserved heterogeneity. Yet, we are left with one problem: We created the WTO variable and the real GDP variable so they are importerexporter-time specific. However, they are not "intrinsically" varying over the importer-exporter dimension, but are just a linear combination of importer-time and exporter-time varying variables. Hence, the transformed real GDP interaction and, more importantly for our purpose, the transformed WTO variable drop out:

$$
\frac{\frac{\left(e_{i j}^{0}, \quad e_{i j}^{1}, \quad e_{i j}^{2}\right)}{\left(e_{i, U S}^{1}, e_{i, U S}^{2}\right)}}{\frac{\left(e_{G E R, j}^{1}, e_{G E R, j}^{2}\right)}{e_{G E R, U S}^{2}}} .
$$

Equation A4 lists all possible outcomes of the WTO variable for each of the four tradeflows. Since both the United States and Germany are members of the WTO for all time periods the variable takes the value two for products exported from Germany to the United States.

Table A3 displays all possible outcome values of the transformed WTO variable in Equation A3.

However, it is clear that, for every possible importer-exporter combination, the transformed WTO variable takes the value one or-after taking the natural logarithm—zero. Hence, no variation is left and the WTO variable would be omitted. We solve that by creating the dummy variable $\overline{W T O}_{i j \tau}$ that is "intrinsically" importer-exporter-time specific and takes one if both countries are members of the WTO and zero otherwise, similar to the GATT variable in Head et al. (2010). We rewrite the population model in Equation A2 with the new WTO variable, an error term, and explicitly modeling unobserved importer-exporter-product heterogeneity. 
T A B L E A 4 Robustness checks-Comparative advantages

\begin{tabular}{|c|c|c|}
\hline & Sample without tariff & $\begin{array}{l}\text { Sample } \\
\text { with tariff }\end{array}$ \\
\hline & (1) & (2) \\
\hline WTO $\times$ DIFF. Good & $0.074 * *$ & $0.075^{* *}$ \\
\hline & $(0.024)$ & $(0.026)$ \\
\hline WTO $\times$ HOM. Good & 0.025 & 0.021 \\
\hline & $(0.029)$ & $(0.034)$ \\
\hline PTA & 0.036 & $0.075^{*}$ \\
\hline & $(0.031)$ & $(0.029)$ \\
\hline PTA Depth × DIFF. Good & -0.004 & $-0.015^{*}$ \\
\hline & $(0.004)$ & $(0.006)$ \\
\hline PTA Depth $\times$ HOM. Good & -0.007 & -0.009 \\
\hline & $(0.006)$ & $(0.007)$ \\
\hline Exporter has CA & -0.007 & -0.001 \\
\hline & $(0.012)$ & $(0.025)$ \\
\hline Importer has CA & $-0.029 * *$ & $-0.045^{* *}$ \\
\hline & $(0.009)$ & $(0.010)$ \\
\hline WTO $\times$ Exporter CA & -0.003 & -0.011 \\
\hline & $(0.006)$ & $(0.011)$ \\
\hline WTO $\times$ Importer CA & $0.014 * *$ & $0.014 * *$ \\
\hline & $(0.004)$ & $(0.004)$ \\
\hline PTA Depth $\times$ Exporter CA & $-0.000 *$ & -0.000 \\
\hline & $(0.000)$ & $(0.000)$ \\
\hline PTA Depth $\times$ Importer CA & -0.000 & $0.000^{*}$ \\
\hline & $(0.000)$ & $(0.000)$ \\
\hline Observations & 33,048 & 24,314 \\
\hline RMSE & 0.959 & 0.946 \\
\hline Adjusted $R^{2}$ & 0.716 & 0.714 \\
\hline $\mathrm{FE}$ & $t \& i j k$ & $t \& i j k$ \\
\hline
\end{tabular}

Note: Robust standard errors are shown in parentheses.

Abbreviations: CA, Comparative advantage; DIFF, differentiated; HOM, homogeneous. Number of observations in 1,000. $* * *, * * *$ Denotes significance at the $1 \%, 5 \%$, and $10 \%$ level, respectively. Robust standard errors two-way clustered by importerexporter-product and time groups, see Cameron et al. (2011).

$$
\text { price }_{k i j \tau}=g d p_{i \tau} g d p_{j \tau} \exp \left(W T O_{i j \tau}\right) \exp \left(\phi_{i \tau}\right) \exp \left(\delta_{j \tau}\right) \exp \left(\omega_{i j k}\right) \exp \left(\epsilon_{i j k \tau}\right) .
$$

Transforming the left-hand side and right-hand side the real GDP interaction and all time-exporter and time-importer specific variation cancels out and we are left with the following estimation equation:

$$
\ln \left(\overline{\operatorname{price}}_{k i j \tau}\right)=\beta_{0}+\beta_{1} \overline{W T O}_{i j \tau}+\bar{\omega}_{k i j}+\bar{\epsilon}_{k i j \tau}
$$

where variables with a bar represent transformed variables according to Equation A1. Decomposing for example the error term into its four elements gives $\bar{\epsilon}_{k i j \tau}=\epsilon_{k i j \tau}-\epsilon_{k i, U S \tau}-\epsilon_{k, G E R, j \tau}+\epsilon_{k, G E R, U S \tau}$. We 
estimate Equation A6 with time fixed effects to capture the last element of the transformed error term and with importer-exporter-product fixed effects to absorb unobserved heterogeneity in the importerexporter-product dimension, $\bar{\omega}_{k i j}$. Errors are clustered over importer-time and exporter-time groups, as Head et al. (2010) shows that error terms are no longer independently distributed if one uses the tetrad method because parts of the (now) composite error reoccur.

\section{A3. Interaction terms with comparative advantage}

We discuss how comparative advantage as a rough proxy for market power in an industry may affect our results. One could argue that the impact of a trade agreement on export prices depends on the degree of market power in an industry. For instance, Lake and Linask (2016) argue that terms of trade motivations imply that a country with higher market power sets a higher optimal tariff to improve its own terms of trade. Hence, market power could affect export prices through the effect on the terms of trade. ${ }^{36}$

We introduce a simple measure of comparative advantage of the exporter and importer, as in Cao and Flach (2015). The measure is taken from Mayda and Rodrik (2005) and is constructed as follows:

$$
C A_{i k t}= \begin{cases}1, & \text { if } M_{i k t}(1-\lambda)-X_{i k t}<0 \\ 0, & \text { if } M_{i k t}(1-\lambda)-X_{i k t}>0\end{cases}
$$

where $M_{i k t}$ are imports of country $i$ in sector $k$ at time $t, X_{i k t}$ are exports of country i in sector $k$ at time $t$ and $\lambda$ is an adjustment defined as follows: $:^{37}$

$$
\lambda=\frac{\sum_{i t}\left(M_{i t}-X_{i t}\right)}{\sum_{i t} M_{i t}} .
$$

This proxy assumes that a country has a comparative advantage if its exports at time $t$ in sector $k$ exceed its imports in this sector at the same time corrected by one minus the adjustment factor. We use the first two digits of the SITC3 industry classification to define a sector. The SITC3 classification of industries can be mapped to the HS classification of products using concordance tables from the UN trade statistics. ${ }^{38}$

The results in Table A4 (columns 1 and 2) reveal that the dummy that indicates a comparative advantage is not significantly correlated with the export price for the exporter, whereas for the importer the effect is negative and significant. Hence, we cannot confirm that the effect of a trade agreement on prices depends on comparative advantages.

Nonetheless, it is interesting to note that the negative partial correlation for the importer is dampened if the importer joins the WTO. It could be argued that it is more difficult for a firm in the exporting country to sell its products to a sector where the importing country has a comparative advantage. To enter sectors in which the importing country has a comparative advantage firms in the exporting country have to lower their prices in order to be competitive enough. If the importer joins the WTO, entering these sectors becomes easier and firms do not have to decrease their prices as much. The counteracting effect is economically irrelevant for the depth of PTAs. Importantly, the magnitude and significance of the WTO coefficients for homogeneous and differentiated products do not change. 


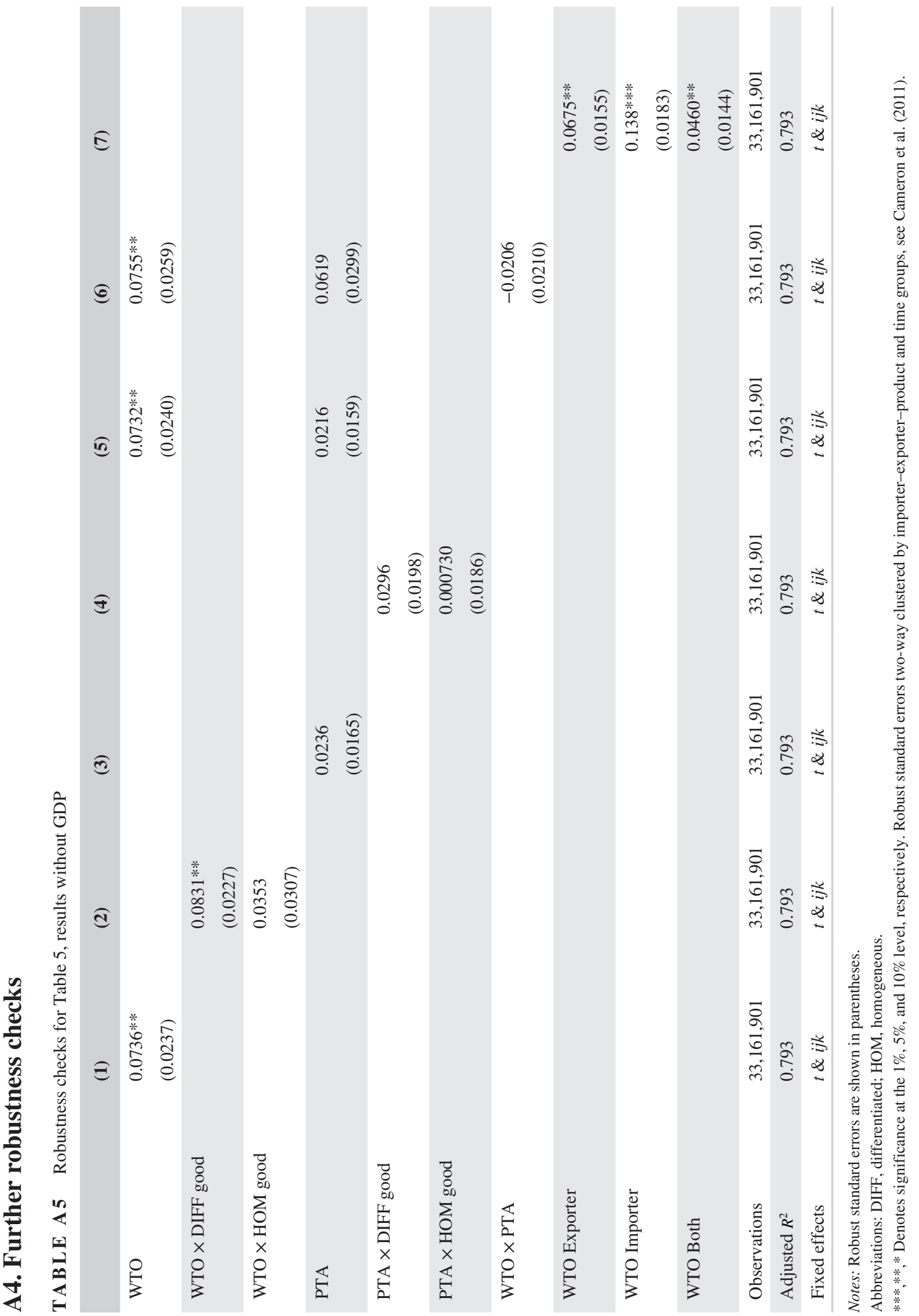




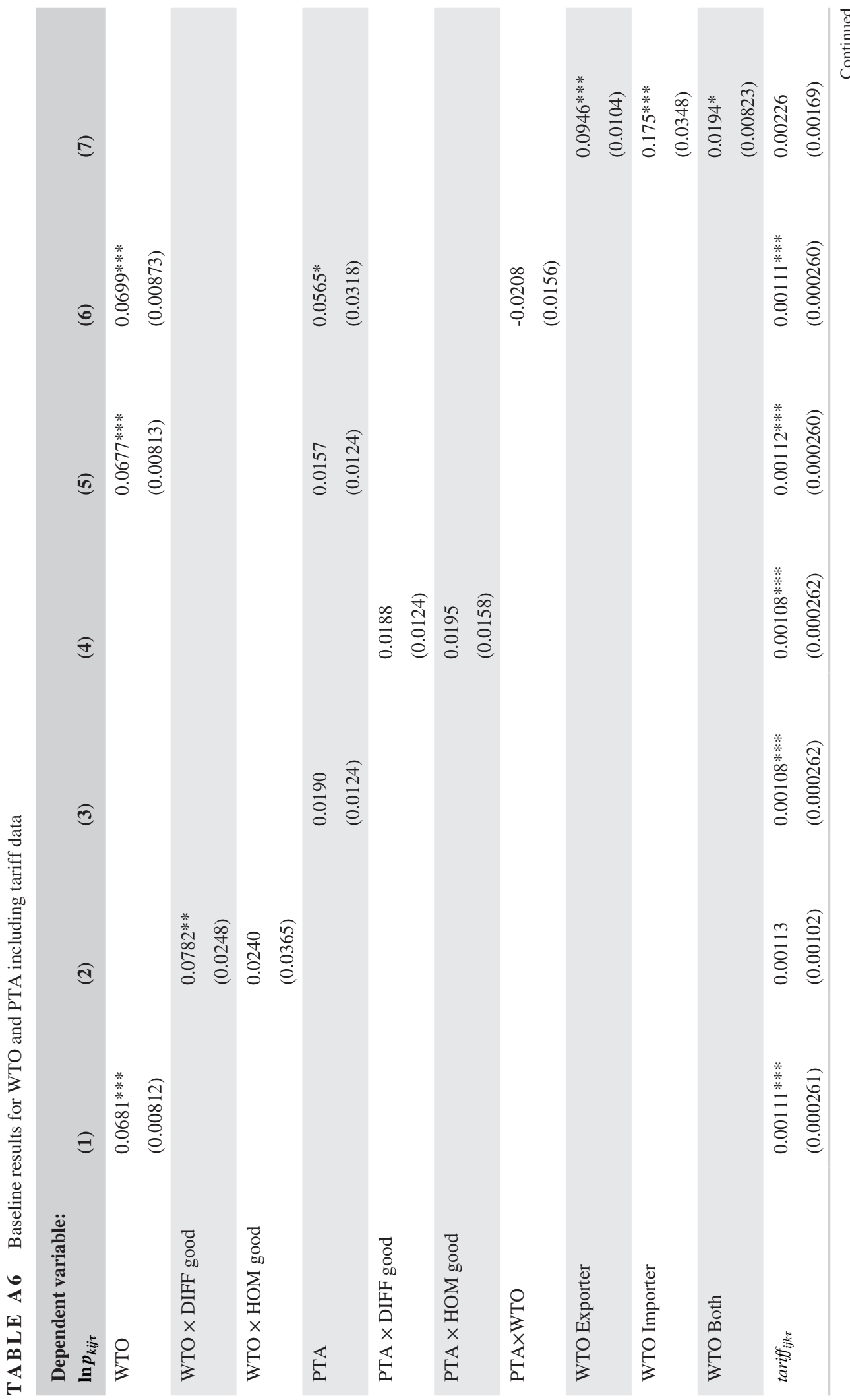




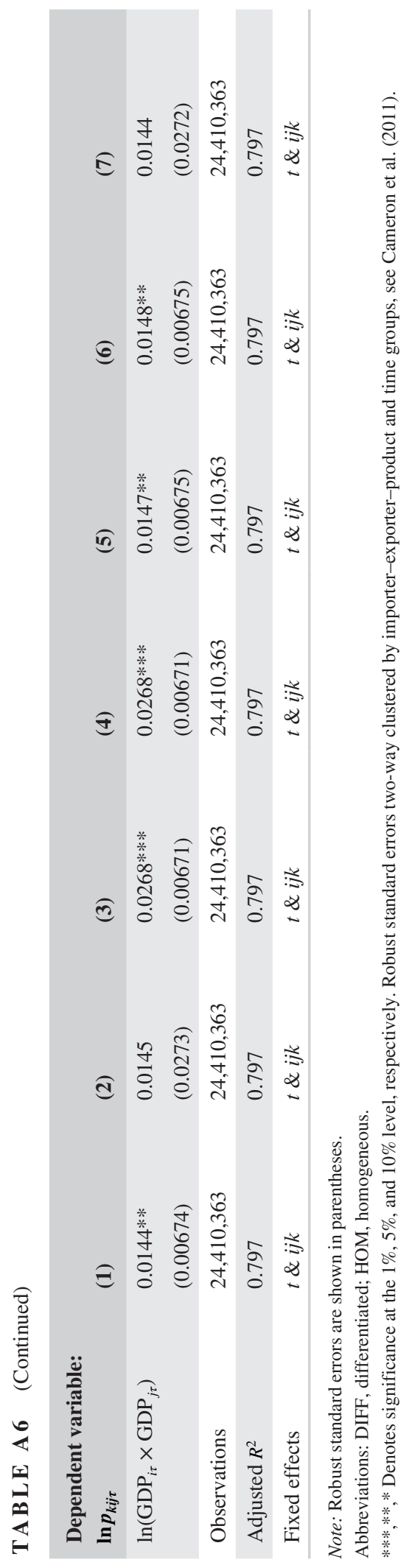




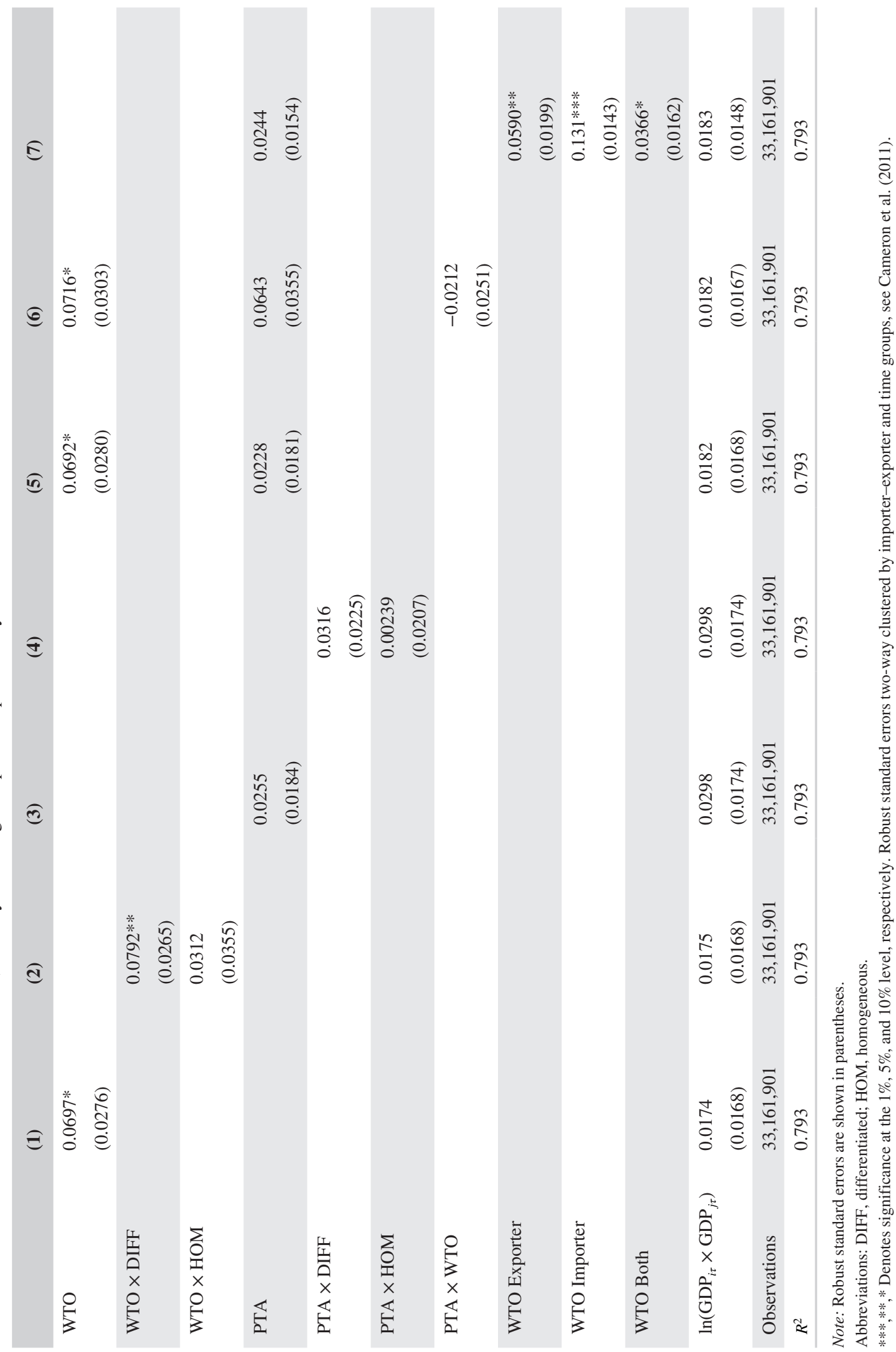


TA B LE A 8 Interaction term between WTO membership and year of entry

\begin{tabular}{lll}
\hline WTO & $(\mathbf{1})$ & $(\mathbf{2})$ \\
& $0.0699^{*}$ & $0.0673^{* *}$ \\
\hline WTO $\times 4$ th year & $(0.0257)$ & $(0.0240)$ \\
\hline WTO $\times 1$ st year & -0.0196 & \\
& $(0.0100)$ & 0.0132 \\
\hline Fixed effects & & $(0.0100)$ \\
\hline Control variable & $t \& i j k$ & $t \& i j k$ \\
\hline Observations & $\ln \left(\mathrm{GDP}_{i \tau} \times \mathrm{GDP}_{j \tau}\right)$ & $\ln \left(\mathrm{GDP}_{i \tau} \times\right.$ \\
$R^{2}$ & & $\left.\mathrm{GDP}_{j \tau}\right)$ \\
\hline
\end{tabular}

Note: Robust standard errors are shown in parentheses.

Abbreviations: DIFF, differentiated; HOM, homogeneous.

$* * *, * *, *$ Denotes significance at the $1 \%, 5 \%$, and $10 \%$ level, respectively. Robust standard errors two-way clustered by importer-exporter-product and time groups, see Cameron et al. (2011). 